\title{
Reliability analysis of structural stainless steel design provisions
}

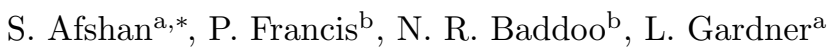 \\ ${ }^{a}$ Imperial College London, London, UK \\ ${ }^{b}$ The Steel Construction Institute, Ascot, UK
}

\begin{abstract}
Since the establishment of the Eurocode design provisions for structural stainless steel, a considerable amount of both statistical material data and experimental results on structural elements has been generated. In light of this, the current partial resistance factors recommended in EN 1993-1-4 for the design of stainless steel elements are re-evaluated. First, following an analysis of material data from key stainless steel producers, representative values of the over-strength and the coefficient of variation $(\mathrm{COV})$ of the material yield strength and ultimate tensile strength were established. For yield strength, over-strength values and COVs of 1.3 and 0.060 for austenitic, 1.1 and 0.030 for duplex and 1.2 and 0.045 for ferritic stainless steels were determined. For the ultimate tensile strength, an over-strength value of 1.1 was found to be suitable for all stainless steel grades, and COV values of 0.035 for the austenitic and duplex grades and 0.05 for the ferritic grade were proposed. For the variability of the geometric properties, a COV value of 0.05 was recommended. Analysis of available experimental results based on the First Order Reliability Method (FORM), set out in EN 1990 Annex D, and utilising the derived statistical material parameters, revealed that the current recommended partial resistance factors in EN 1993-1-4 $\left(\gamma_{\mathrm{M} 0}=\gamma_{\mathrm{M} 1}=1.1\right.$ and $\left.\gamma_{\mathrm{M} 2}=1.25\right)$ cannot generally be reduced, and in some cases, modified design resistance equations are required, if the current safety factors are to be maintained.

Keywords: Material over-strength, Partial factors, Reliability, Stainless steel, Statistical parameters, Variability
\end{abstract}

\section{Introduction}

Partial factors are employed within the limit state design methodology, as adopted in Eurocodes, to limit the probability of failure of a structure. The partial resistance factors, known as $\gamma_{\mathrm{M}}$ factors in the Eurocodes, are numerical values that allow for uncertainties in the material properties, the geometric properties and the accuracy of the design resistance function. Calibration of the codified design resistance equations, using reliability methods to achieve a certain target reliability requirement, lead into the determination of partial

\footnotetext{
* Corresponding author

Email address: sheida.afshan06@imperial.ac.uk (S. Afshan)
} 
resistance factors for design. Three partial safety factors, $\gamma_{\mathrm{M} 0}, \gamma_{\mathrm{M} 1}$ and $\gamma_{\mathrm{M} 2}$ are used in EN 1993-1-4 [1] for the design of stainless steel structural members. $\gamma_{\mathrm{M} 0}$ is used in cross-section design checks, $\gamma_{\mathrm{M} 1}$ is employed in member instability design checks and $\gamma_{\mathrm{M} 2}$ is used in expressions for determining the resistance of crosssections in tension and the resistance of bolted and welded connections. The recommended values in EN 1993-1-4 [1] are: $\gamma_{\mathrm{M} 0}=\gamma_{\mathrm{M} 1}=1.1$ and $\gamma_{\mathrm{M} 2}=1.25$. In light of a substantially increased pool of available experimental results and statistical material and geometric data, the objective of this study is to re-evaluate these recommended partial factors for both member and connection resistance.

The paper begins with a brief summary of the theoretical background of the reliability method adopted in the Eurocodes, as outlined in EN 1990 [2]. The statistical data on material and geometric properties of structural stainless steel sections from the literature and stainless steel producers are then presented. Finally, reliability assessments of the EN 1993-1-4 [1] design resistance equations are carried out, covering: cross-sections in compression, flexural buckling, torsional-flexural buckling, in-plane bending, lateral-torsional buckling, shear buckling and welded and bolted connections.

\section{Methodology for the statistical evaluation of resistance models}

\subsection{Theoretical background}

Eurocode 3 employs a range of resistance functions for determining the capacity of steel structures. The safety assessment and the choice of safety factors used with these resistance functions is based on a statistical evaluation of relevant experimental data, carried out within the framework of a probabilistic reliability theory. Within the adopted first order reliability method (FORM), the probability of failure, $P_{f}$, i.e. the probability that the resistance $(R)$ minus the action effect $(E)$ is less than zero, is set out in terms of the total reliability index $\beta$, as defined in Equation (1), where $\phi$ is the cumulative distribution function of the standardised Normal distribution. The target reliability index is selected based on a series of consequence classes (CC) which are directly related to the reliability classes (RC), as defined in Annex C of EN 1990 [2]. Typical building structures will fall into reliability class $\mathrm{RC} 2$ with reference design life of 50 years and a target reliability index of 3.8 for ultimate limit state design [2]. This value has been adopted in the analyses performed in this paper.

$$
\mathrm{P}_{\mathrm{f}}=\mathrm{P}[(\mathrm{R}-\mathrm{E}) \leq 0]=\phi(-\beta)
$$

Treating both resistance (R) and action effects (E) together, where the variabilities associated with both parameters are considered in a combined manner to determine the reliability of a structure, based on Equation (1), is considered infeasible and is not recommended for calibration of codified design rules [3]. Therefore, a 
semi-probabilistic approach, where the variabilities of the load effects and resistance functions are assessed separately has been used in EN 1990 [2], through the use of FORM sensitivity factors $\alpha_{\mathrm{E}}$ and $\alpha_{\mathrm{R}}$, resulting in Equations (2) and (3) for the action effect and resistance, respectively, where $\mathrm{E}_{\mathrm{d}}$ is the design action effect and $R_{d}$ is the design resistance.

$$
\begin{gathered}
\mathrm{P}\left(\mathrm{E}>\mathrm{E}_{\mathrm{d}}\right)=\phi\left(\alpha_{\mathrm{E}} \beta\right) \\
\mathrm{P}\left(\mathrm{R} \leq \mathrm{R}_{\mathrm{d}}\right)=\phi\left(\alpha_{\mathrm{R}} \beta\right)
\end{gathered}
$$

Therefore, for the purpose of calibrating a new design procedure and establishing the partial safety factors that yield the total target reliability, only Equation (3) needs to be considered. The sensitivity factors may be approximately taken as $\alpha_{\mathrm{E}}=-0.7$ and $\alpha_{\mathrm{R}}=+0.8$, provided that the ratio of the standard deviation of the action effect $\sigma_{\mathrm{E}}$ and resistance $\sigma_{\mathrm{R}}$ is such that $0.16 \leq \sigma_{\mathrm{E}} / \sigma_{\mathrm{R}} \leq 7.6$ [2]. This means that for reliability class $\mathrm{RC} 2$, the probability of the resistance of structural components falling below the design resistance is as given in Equation (4).

$$
\mathrm{P}\left(\mathrm{R} \leq \mathrm{R}_{\mathrm{d}}\right)=\phi(-0.8 \times 3.8) \simeq 0.001
$$

The partial resistance factor $\gamma_{\mathrm{M}}$, given in Equation (5) is defined as the ratio of the nominal resistance value $\mathrm{r}_{\mathrm{n}}$, determined from the design resistance equation under consideration, using the nominal geometric and material properties, and the design resistance value $r_{d}$, determined from the reliability analysis procedures using the values of basic variables measured during testing.

$$
\gamma_{\mathrm{M}}=\mathrm{r}_{\mathrm{n}} / \mathrm{r}_{\mathrm{d}}
$$

\subsection{EN 1990 Annex D method}

In Annex D of EN 1990 [2], a set of application rules for obtaining the design values for a resistance function through a statistical evaluation of experimental data is provided. The method begins by comparing the theoretical resistance values $r_{t, i}$ obtained from the resistance function under consideration $g_{r t}(\underline{X})$, using the measured material and geometric properties, with the experimental resistance values $r_{e, i}$ from each test, through a plot of $\mathrm{r}_{\mathrm{e}, \mathrm{i}}$ versus $\mathrm{r}_{\mathrm{t}, \mathrm{i}}$ values. An error term $\delta_{\mathrm{i}}=\mathrm{r}_{\mathrm{e}, \mathrm{i}} / \mathrm{br}_{\mathrm{t}, \mathrm{i}}$, is calculated for each $\left(\mathrm{r}_{\mathrm{t}, \mathrm{i}}, \mathrm{r}_{\mathrm{e}, \mathrm{i}}\right)$ data pair, showing the deviation of the experimental resistance values to the mean strength function $r_{e}=b r_{t}$, where $\mathrm{b}$ is the mean value correction factor obtained as the least squares best fit of the slope of the $\mathrm{r}_{\mathrm{e}, \mathrm{i}}$ versus $\mathrm{r}_{\mathrm{t}, \mathrm{i}}$ plot. The coefficient of variation of this error term $\mathrm{V}_{\delta}$ is used as a measure of the variabilities associated with 
the predictions from the resistance function. Considering the logarithmic normal probability distribution of $\delta_{\mathrm{i}}$, the coefficient of variation of the error term is given by Equation (6), where $\sigma_{\delta}^{2}$ is the corresponding variance.

$$
\mathrm{V}_{\delta}=\sqrt{\exp \left(\sigma_{\delta}^{2}\right)-1}
$$

If the scatter of the predictions is too high, i.e. large $\mathrm{V}_{\delta}$ values, to give an economical design resistance model, procedures to reduce the scatter are required. The scatter may be reduced by improving the design model to take into account parameters which had previously been ignored, or by modifying the parameters $\mathrm{b}$ and $\mathrm{V}_{\delta}$ by dividing the total test population into appropriate sub-sets for which the influence of such additional parameters may be considered to be constant. In this study, the test data have been split into sub-sets based on their material grade, as explained in more detail in Section 3. The disadvantage of splitting the test results into sub-sets is that the number of test results in each sub-set can become very small. In order to avoid unreasonably large safety factors as a result of this, Clause D.8.2.2.5 of EN 1990 Annex D [2] allows the use of the total number of tests in the original series for determining the $\mathrm{k}_{\mathrm{d}, \mathrm{n}}$ fractile factor. Hence, in this study the $\mathrm{k}_{\mathrm{d}, \mathrm{n}}$ for each sub-set was based on the total number of tests for all stainless steel grades, for the cross-section shape and failure mode under consideration.

The effect of the variability of the basic variables in the resistance function $\mathrm{g}_{\mathrm{rt}}(\underline{\mathrm{X}})$, including material and geometric properties, is also accounted for through their coefficient of variation parameter, $\mathrm{V}_{\mathrm{rt}}$. There are two methods of calculating $\mathrm{V}_{\mathrm{rt}}$, depending on the level of complexity of the resistance function under consideration. For the case of complex and multi-variable resistance functions, such as the column buckling formula in EN 1993-1-4 [1], $V_{r t}$ may be obtained from Equation (7), where $g_{r t}\left(\underline{X}_{m}\right)$ is the resistance function evaluated for the mean values of the basic variables and $\frac{\partial \mathrm{g}_{\mathrm{rt}}}{\partial \mathrm{x}_{\mathrm{i}}} \cdot \sigma_{\mathrm{i}}$ is the partial derivative for the variable $X_{i}$ multiplied by its respective standard deviation $\sigma_{i}$. Equation (8) is deemed sufficient for resistance functions of simpler form, such as that for the bending resistance of laterally restrained beams, where the coefficient of variation of each of the basic variables $V_{X i}$ is used directly. The analyses carried out in this paper have made use of both methods as appropriate; this is explained in more detail in Section 4. The coefficients of variation $\mathrm{V}_{\mathrm{Xi}}$ of the basic variables are generally determined on the basis of prior knowledge, and have been obtained herein using representative data from stainless steel producers as discussed in more detail in Section 3.

$$
\mathrm{V}_{\mathrm{rt}}^{2}=\frac{\mathrm{VAR}\left[\mathrm{g}_{\mathrm{rt}}(\underline{\mathrm{X}})\right]}{\mathrm{g}_{\mathrm{rt}}^{2}\left(\underline{\mathrm{X}}_{\mathrm{m}}\right)} \cong \frac{1}{\mathrm{~g}_{\mathrm{rt}}^{2}\left(\underline{\mathrm{X}}_{\mathrm{m}}\right)} \cdot \sum_{\mathrm{i}=1}^{\mathrm{j}}\left(\frac{\partial \mathrm{g}_{\mathrm{rt}}}{\partial \mathrm{x}_{\mathrm{i}}} \cdot \sigma_{\mathrm{i}}\right)^{2}
$$




$$
\mathrm{V}_{\mathrm{rt}}^{2}=\sum_{\mathrm{i}=1}^{\mathrm{j}} \mathrm{V}_{\mathrm{Xi}^{2}}{ }^{2}
$$

Finally, the design resistance value $r_{d}$, leading to the determination of the partial factor $\gamma_{M}$ is obtained from Equation (9), which applies in cases of a limited number of test results $(\mathrm{n} \leq 100)$. In Equation (9), b is the mean value correction factor, $\mathrm{g}_{\mathrm{rt}}\left(\underline{\mathrm{X}}_{\mathrm{m}}\right)$ is the design resistance evaluated for the mean values of the basic variables, $\mathrm{k}_{\mathrm{d}, \mathrm{n}}$ is the design fractile factor and $\mathrm{k}_{\mathrm{d}, \infty}$ is the design fractile factor for $\mathrm{n}$ tending to infinity $\left(\mathrm{k}_{\mathrm{d}, \infty}=3.04\right)$. The following parameters: $\alpha_{\mathrm{rt}}=$ weighting factor for $\mathrm{Q}_{\mathrm{rt}}, \alpha_{\delta}=$ weighting factor for $\mathrm{Q}_{\delta}, \mathrm{Q}_{\mathrm{rt}}$, $\mathrm{Q}_{\delta}$ and $\mathrm{Q}$ - as defined by Equations (10), (11), (12), (13) and (14), respectively are used to simplify the representation of the calculations.

$$
\begin{gathered}
\mathrm{r}_{\mathrm{d}}=\operatorname{bg}_{\mathrm{rt}}\left(\underline{\mathrm{X}}_{\mathrm{m}}\right) \exp \left(-\mathrm{k}_{\mathrm{d}, \infty} \alpha_{\mathrm{rt}} \mathrm{Q}_{\mathrm{rt}}-\mathrm{k}_{\mathrm{d}, \mathrm{n}} \alpha_{\delta} \mathrm{Q}_{\delta}-0.5 \mathrm{Q}^{2}\right) \\
\alpha_{\mathrm{rt}}=\mathrm{Q}_{\mathrm{rt}} / \mathrm{Q} \\
\alpha_{\delta}=\mathrm{Q}_{\delta} / \mathrm{Q} \\
\mathrm{Q}_{\mathrm{rt}}=\sqrt{\ln \left(\mathrm{V}_{\mathrm{rt}}^{2}+1\right)} \\
\mathrm{Q}_{\delta}=\sqrt{\ln \left(\mathrm{V}_{\delta}^{2}+1\right)} \\
\mathrm{Q}=\sqrt{\ln \left(\mathrm{V}_{\mathrm{r}}^{2}+1\right)}, \operatorname{with} \mathrm{V}_{\mathrm{r}}^{2}=\mathrm{V}_{\delta}^{2}+\mathrm{V}_{\mathrm{rt}}^{2}
\end{gathered}
$$

\section{Statistical data on material and geometric parameters}

In this section, statistical data from stainless steel producers are presented and analysed. From the analysis, representative values of over-strength and coefficient of variation for the yield strength and ultimate tensile strength of austenitic, duplex and ferritic stainless steels are proposed. Mean values and variability of geometric properties are also assessed. 


\subsection{Statistical data on yield strength}

Mean values and standard deviations for the yield strength, taken as the $0.2 \%$ proof stress, of different stainless steel grades were collected from a number of major European stainless steel producers and from the literature [4-8]. Where a number of grades were reported, average values for each stainless steel type austenitic, duplex and ferritic - were determined. A summary of the results is presented in Table 1, where the data within each stainless steel type have been grouped based on the product type - cold-rolled coil/sheet (C), hot-rolled coil/sheet $(\mathrm{H})$ and hot-rolled plate $(\mathrm{P})$. Since the data from the stainless steel producers were provided on a confidential basis, the identity of the producers have not been stated and the source is simply indicated as Producer.

The ratio of mean to minimum specified yield strength $f_{y, \text { mean }} / f_{y, \text { min }}$ and the coefficient of variation (COV) of the mean yield strength are also provided in Table 1. The minimum yield strength values were obtained from EN 10088-4 [9]. One of the assumptions made in the reliability analysis procedures set out in EN 1990Annex D is that the minimum (nominal) yield strength, $\mathrm{f}_{\mathrm{y}, \mathrm{min}}$, is a characteristic value and should therefore correspond to the $95 \%$ confidence limit. The characteristic yield strengths $\mathrm{f}_{\mathrm{y}, \mathrm{k}}$ corresponding to each set of $\mathrm{f}_{\mathrm{y}, \text { mean }}$ and standard deviation $\sigma$ data have been evaluated, and the ratios of $\mathrm{f}_{\mathrm{y}, \mathrm{k}} / \mathrm{f}_{\mathrm{y}, \text { min }}$ are reported in Table 1. The fact that the values of $\mathrm{f}_{\mathrm{y}, \mathrm{k}} / \mathrm{f}_{\mathrm{y}, \mathrm{min}}$ are greater than unity indicates that the assumption that nominal yield strength is a characteristic value is conservative; this has also been found for the case of carbon steel [10]. Benefit may be derived from the margin between the nominal and characteristic strength in the reliability analysis, thorough the use of the over-strength parameter $f_{y, \text { mean }} / f_{y, \text { min }}$, where $f_{y, \text { mean }}$ is the mean value produced by stainless steel manufacturers and $\mathrm{f}_{\mathrm{y}, \min }$ is the minimum specified value in EN 10088-4 [9].

During the initial calibration of the EN 1993-1-4 [1] design rules, the over-strength factor for the material yield strength $\mathrm{f}_{\mathrm{y}, \mathrm{mean}} / \mathrm{f}_{\mathrm{y} \text {, min }}$ was taken as 1.33 with a COV value of 0.066 for all stainless steels [11]. Analyses of the results in this study have shown that, in fact, these statistical parameters vary between the different stainless steel types, and their effect needs to be allowed for in the reliability analysis by dividing the structural performance data into sub-sets based on their material grade. From the assembled data in Table 1 , on average, the austenitic grades exhibit the highest ratio of $f_{y, m e a n} / f_{y}$, min of 1.40 , the lowest of 1.20 is shown by the duplex grades, and an intermediate value of 1.38 is observed for the ferritic grades.

The range of $\mathrm{f}_{\mathrm{y}, \text { mean }} / \mathrm{f}_{\mathrm{y} \text {, min }}$ values for the different stainless steels is 1.34 - 1.54 for the austenitic grades, $1.04-1.33$ for the duplex grades and $1.21-1.51$ for the ferritic grades. In the present study, representative but conservative values of over-strength were sought. Hence, based generally on the minimum over-strength values from the different sources (producers), values of 1.3, 1.1 and 1.2 for the austenitic, duplex and ferritic 
grades, respectively were considered appropriate for use in the reliability analyses.

The coefficients of variation of the yield strength are plotted against the $f_{y, \text { mean }} / f_{y, \text { min }}$ ratio for all grades in Figure 1. The data reveals a clear trend, common to all grades, of reducing COV with reducing $f_{y, m e a n} / f_{y, m i n}$. This would be anticipated since, as the $\mathrm{f}_{\mathrm{y}, \mathrm{mean}} / \mathrm{f}_{\mathrm{y} \text {, min }}$ ratio approaches unity, tighter controls would be required by the manufacturers to ensure that the material satisfies the minimum requirements. The linear regression relationship between the $\mathrm{f}_{\mathrm{y} \text {, mean }} / \mathrm{f}_{\mathrm{y} \text {, min }}$ ratio and COV values, shown in Figure 1, was used to obtain COV values corresponding to the adopted over-strength factors. The COV values were equal to 0.060, 0.030 and 0.045 for the austenitic, duplex and ferritic grades, respectively.

\subsection{Statistical data on ultimate tensile strength}

A similar analysis to that described above was carried out for the ultimate tensile strength $\mathrm{f}_{\mathrm{u}}$ of stainless steel, and the results are summarised in Table 2. The over-strength factor for the ultimate tensile strength $\mathrm{f}_{\mathrm{u}, \text { mean }} / \mathrm{f}_{\mathrm{u}, \text { min }}$ fell into a tight range of between 1.06 and 1.23 for all stainless steel grades. Hence, a single over-strength value $f_{u, \text { mean }} / f_{u, \text { min }}$, common to all stainless steel grades of 1.1 , which is close to the lower end of this range, was deemed appropriate for use in reliability analyses. Also, owing to the relatively narrow band

of $f_{u, m e a n} / f_{u, m i n}$, no clear correlation between the over-strength and the associated COV, as had been seen for the case of the yield strength, could be established. Therefore, considering the range of COV values obtained from the individual sources for the austenitic and duplex stainless steel grades, 0.017-0.034 and 0.010-0.038, respectively, a common COV value towards the upper end of these ranges of 0.035 is proposed. To allow for the generally larger scatter obtained from the individual sources for the ferritic material, 0.024-0.068, a higher $\mathrm{COV}$ value of 0.05 is proposed herein. This value is towards the upper end of the range of COV values from the individual sources and is only exceeded by two data sets, both with $f_{u, \text { mean }} / f_{u, \text { min }}=1.14$, which is higher than the adopted value of 1.1, and would therefore be expected to off-set the effect of the lower COV adopted.

\subsection{Statistical data on geometrical properties}

The dimensional variation of stainless steel elements is another source of variability in member resistance, and needs to be appropriately accounted for in the reliability analysis. In the absence of detailed records of dimensional variations from stainless steel section manufacturers, the required statistical information were obtained by studying the dimensional variation of test specimens from the collected database of structural performance data used in Section 4. Assuming that the test specimens are representative of sections used in practical applications, the magnitudes of all the key measured dimensions were compared against the corresponding nominal dimensions, enabling the determination of mean values and standard deviations for 
the ratios of the measured to nominal properties of different section types. Summaries of the obtained results for a total of 282 square and rectangular hollow sections (SHS and RHS), 74 circular hollow sections (CHS) and 62 I-sections are presented in Tables 3, 4 and 5, respectively.

The analysis indicated that, on average, sections tend to be marginally smaller than their nominal dimensions; however, the difference is considered insignificant and no correction for this discrepancy was included in the statistical reliability analysis, while due allowance for the obtained variability was made. Since the effect of the variability of the individual geometric parameters depends on the resistance function being considered, an overall coefficient of variation $V_{\text {geometry }}$ parameter may be employed for different resistance functions. A method based on Equation (7) was used herein, where weighting factors associated with each geometric variable were evaluated, and used with the dimensional variation data presented in Tables 3, 4 and 5 , to determine suitable $\mathrm{V}_{\text {geometry }}$ parameters. Since the value of the weighting factors depend on the resistance function being considered, it is possible to have different $V_{\text {geometry }}$ values for a given section type used in different resistance functions. Values of $\mathrm{V}_{\text {geometry }}$ were determined for SHS/RHS, CHS and I-sections for compression and bending loading cases. A summary of the results from this analysis is presented in Table 6 , and a detailed description of the method used in determining these values are provided in Appendix A. On a similar basis, Byfield and Nethercot [10] adopted a value of $\mathrm{V}_{\text {geometry }}=0.02$ for carbon steel Isections in compression and bending, while a larger value of $\mathrm{V}_{\text {geometry }}=0.05$ was utilised for stainless steel in the development of the AISC stainless steel design guide [12]. Analysis of the results herein shows that $\mathrm{V}_{\text {geometry }}=0.05$ is more appropriate for stainless steel sections; this value was adopted in all the reliability analyses carried out in this paper.

\section{Determination of partial resistance factors and assessment of EN 1993-1-4}

In this section, the reliability analysis procedures set out in Annex D of EN 1990 [2], as introduced in Section 2, along with the statistical data on material and geometric properties, presented in Section 3, have been applied to an extensive pool of structural performance data on stainless steel members and connections to assess the partial factors for the resistance functions provided in EN 1993-1-4 [1]. At the cross-section level, stub column and in-plane bending test results were used to assess the $\gamma_{\mathrm{M} 0}$ partial resistance factor. At the member level, flexural buckling, torsional-flexural, lateral-torsional buckling and shear buckling buckling test results were used to evaluate the $\gamma_{\mathrm{M} 1}$ partial resistance factor. Test results on both bolted and welded connections were also gathered to examine the $\gamma_{\mathrm{M} 2}$ partial resistance factor for connection design. The classification of the cross-sections for the treatment of local buckling was based on the recent classification limits and effective width equations proposed by Gardner and Theofanous [13], which will replace 
the current guidelines in the forthcoming amendment to EN 1993-1-4 [1], which is due to be published in 2015.

\subsection{Partial factor for cross-section resistance $\gamma_{\mathrm{M} 0}$}

The compression resistance of a stainless steel cross-section $\mathrm{N}_{\mathrm{c}, \mathrm{Rd}}$, as set out in EN 1993-1-4 [1], is given by Equation (15), where $\mathrm{f}_{\mathrm{y}}$ is the material yield strength and $\mathrm{A}$ is the cross-sectional area, taken as the gross cross-sectional area for Class 1, 2 and 3 sections and the effective cross-sectional area $\mathrm{A}_{\text {eff }}$ for Class 4 sections. The design moment resistance of a cross-section subjected to uniaxial bending $\mathrm{M}_{\mathrm{c}, \mathrm{Rd}}$ is given by Equation (16), where $\mathrm{W}$ is the appropriate section modulus, taken as the plastic section modulus $\mathrm{W}_{\mathrm{pl}}$ for Class 1 and 2 sections, the elastic section modulus $\mathrm{W}_{\text {el }}$ for Class 3 sections and $\mathrm{W}_{\text {eff }}$ for Class 4 sections.

$$
\begin{aligned}
\mathrm{N}_{\mathrm{c}, \mathrm{Rd}} & =\frac{\mathrm{Af}_{\mathrm{y}}}{\gamma_{\mathrm{M} 0}} \\
\mathrm{M}_{\mathrm{c}, \mathrm{Rd}} & =\frac{\mathrm{Wf} \mathrm{f}_{\mathrm{y}}}{\gamma_{\mathrm{M} 0}}
\end{aligned}
$$

Test data on stainless steel stub columns $[11,14-28]$ and beams $[11,16,17,17,25,29-38]$ were collected and used to assess the partial factors $\gamma_{\mathrm{M} 0}$ employed in Equations (15) and (16). Owing to the relatively simple form of these design resistance functions, Equation (8) was used to calculate the coefficient of variation of the model $V_{\text {rt }}$, with the the coefficient of variation of the basic variables $V_{\mathrm{Xi}}$ taken as those presented in Section 3. The results of the statistical analysis for the two populations of data for cross-sections in compression and cross-sections in bending are reported in Tables 7 and 8 , respectively. The $\mathrm{k}_{\mathrm{d}, \mathrm{n}}$ parameter is the fractile factor, and is related to the number of tests in each data set. For SHS/RHS, $\mathrm{k}_{\mathrm{d}, \mathrm{n}}$ was determined on the basis of the total pool of compression test data on this section type, including both stub columns and long columns. A similar approach was taken for I-sections and CHS, while the test data on angle, channel and lipped channel sections were combined to determine a common $\mathrm{k}_{\mathrm{d}, \mathrm{n}}$ value for these sections. The resulting values of $\mathrm{k}_{\mathrm{d}, \mathrm{n}}$ are reported in 7 .

The required values of $\gamma_{\mathrm{M} 0}$ for cross-section compression resistance derived from the statistical analyses are reported in Table 7. For SHS/RHS and I-sections, the current $\gamma_{\mathrm{M} 0}$ value of 1.1 is found to be sufficient for all stainless steel grades considered. Test data on stainless steel open sections such as channles, lipped channels and angles, are relatively limited, and the data used in this study were acquired from a single source [23], based on which it is indicated that a $\gamma_{\mathrm{M} 0}$ value higher than 1.1 may be required. However, it is recommended that the current $\gamma_{\mathrm{M} 0}$ value of 1.1 should be maintained for these section types in the absence of a comprehensive set of structural performance test or FE data. Analysis of the CHS data suggests that 
while $\gamma_{\mathrm{M} 0}=1.1$ is conservative for the case of duplex and ferritic grades, it needs to be increased for the case of austenitic stainless steels. A high $\gamma_{\mathrm{M} 0}$ value of 1.32 for the austenitic grade is mainly as a result of a combination of low $\mathrm{b}$ and high $\mathrm{V}_{\delta}$ values for this material. Figure 2 shows the results of all CHS test data, including long columns, where the reduction factor $\chi=\mathrm{N}_{\text {test }} / \mathrm{Af}_{\mathrm{y}}$ is plotted against the member slenderness $\bar{\lambda}$. It shows that the current plateau length of $\bar{\lambda}_{0}=0.4$ as adopted in EN 1993-1-4 [1], below which member buckling checks are not required, is rather optimistic for CHS members. This elongated plateau length influences the results of the statistical analysis on cross-section compression resistance, and contributes to a high required value of $\gamma_{\mathrm{M} 0}$ for the austenitic material, which features test data towards the end of the plateau. The member buckling curves given in of EN 1993-1-4 [1] for the design of stainless steel compression members are known to require reconsideration [39]; This is the subject of ongoing research and will be discussed further in subsequent sections.

The statistical analysis results presented in Table 8 suggest that the EN 1993-1-4 [1] design resistance equation for cross-section bending capacity is consistently conservative for austenitic, duplex and ferritic stainless steels, and considering the $\gamma_{\mathrm{M} 0}$ value for all cross-section types and grades included for this loading type, it is proposed that the current value of 1.1 is maintained.

\subsection{Partial factor for member resistance $\gamma_{\mathrm{M} 1}$}

The member buckling resistance expressions set out in EN 1993-1-4 [1], for all buckling modes (flexural, torsional-flexural, lateral-torsional and shear buckling) are of the same generic form and the method for determining the member buckling resistance is common. The member buckling resistance formulations depend on the reduction factor $\chi$, yield strength $\mathrm{f}_{\mathrm{y}}$ and a geometric property - cross-sectional area A for flexural buckling and torsional-flexural buckling, shear area $\mathrm{A}_{\mathrm{v}}$ for shear buckling and major axis section modulus $\mathrm{W}_{\mathrm{y}}$ for lateral-torsional buckling. However, the latter parameters $\left(\mathrm{f}_{\mathrm{y}}, \mathrm{A}\right.$ and $\left.\mathrm{W}_{\mathrm{y}}\right)$ also feature in determining the buckling reduction factor $\chi$, which implies that unlike the assumption made in the reliability analysis procedures outlined in Annex D of EN 1990 [2], the basic variables are not independent in these design expressions. Therefore, a method for separating the dependence of the basic variables in the member buckling resistance functions is first required before the reliability analysis procedures can be applied. Such a method is described herein; a detailed explanation of the method is presented for the case of flexural buckling, and its key aspects as applied to other loading cases are highlighted in subsequent relevant sections. 


\subsubsection{Flexural buckling resistance}

The flexural buckling resistance of a stainless steel compression member $\mathrm{N}_{\mathrm{b}, \mathrm{Rd}}$, as set out in EN 1993-1-4 [2], is given by Equation (17), where $\mathrm{f}_{\mathrm{y}}$ is the material yield strength, $\mathrm{A}$ is the cross-sectional area (taken as the gross cross-sectional area for Class 1, 2 and 3 sections and effective cross-sectional area $\mathrm{A}_{\text {eff }}$ for Class 4 sections), $\gamma_{\mathrm{M} 1}$ is the partial resistance factor for member resistance and $\chi$ is the flexural buckling reduction factor, determined from Equation (18).

$$
\mathrm{N}_{\mathrm{b}, \mathrm{Rd}}=\frac{\chi \mathrm{Af}_{\mathrm{y}}}{\gamma_{\mathrm{M} 1}} \quad \text { for } \bar{\lambda}>\bar{\lambda}_{0}
$$

in which the flexural buckling reduction factor $\chi$ is given by:

$$
\chi=\frac{1}{\phi+\sqrt{\phi^{2}-\bar{\lambda}^{2}}} \leq 1.0 \quad \text { with } \phi=0.5\left[1+\alpha\left(\bar{\lambda}-\bar{\lambda}_{0}\right)+\bar{\lambda}^{2}\right] \quad \text { and } \bar{\lambda}=\sqrt{\mathrm{Af}_{\mathrm{y}} / \mathrm{N}_{\mathrm{cr}}}
$$

where $\mathrm{N}_{\mathrm{cr}}$ is the elastic critical buckling load, $\alpha$ is the imperfection factor and $\bar{\lambda}_{0}$ is the non-dimensional limiting slenderness (i.e. the plateau length). For cold-formed open sections and hollow sections, $\bar{\lambda}_{0}=0.4$ and $\alpha=0.49$, for welded open sections (buckling about the major axis) $\bar{\lambda}_{0}=0.2$ and $\alpha=0.49$ and for welded open sections (buckling about the minor axis) $\bar{\lambda}_{0}=0.2$ and $\alpha=0.76$.

In order to separate the dependency of the buckling reduction factor $\chi$ on the other basic variables in the design model, $\mathrm{f}_{\mathrm{y}}$ and $\mathrm{A}$, given in Equation (17), the resistance function may be expressed as given in Equation (19) where, $\mathrm{k}$ is the model constant, independent of $\mathrm{A}$ and $\mathrm{f}_{\mathrm{y}}$, and $\mathrm{c}$ and $\mathrm{d}$ are the model parameters specific to each test specimen and vary with column slenderness $\bar{\lambda}$.

$$
\mathrm{N}_{\mathrm{b}, \mathrm{Rd}}=\mathrm{kf}_{\mathrm{y}}{ }^{\mathrm{c}} \mathrm{A}^{\mathrm{d}}
$$

The approach to determine the parameters $\mathrm{c}$ and $\mathrm{d}$ for each specific test specimen are outlined herein. Considering two columns with the same cross-sectional area $A$ and different yield strength values $\mathrm{f}_{\mathrm{y}, 1}$ and $\mathrm{f}_{\mathrm{y}, 2}$, using Equation (19) the ratio of their capacities becomes:

$$
\frac{\mathrm{N}_{\mathrm{b}, \mathrm{Rd}, 2}}{\mathrm{~N}_{\mathrm{b}, \mathrm{Rd}, 1}}=\frac{\mathrm{kf}_{\mathrm{y}, 2}{ }^{\mathrm{c}} \mathrm{A}^{\mathrm{d}}}{\mathrm{kf}_{\mathrm{y}, 1}{ }^{\mathrm{c}} \mathrm{A}^{\mathrm{d}}}=\left(\frac{\mathrm{f}_{\mathrm{y}, 2}}{\mathrm{f}_{\mathrm{y}, 1}}\right)^{\mathrm{c}}
$$

Hence, c may be determined as:

$$
\mathrm{c}=\frac{\ln \left(\mathrm{N}_{\mathrm{b}, \mathrm{Rd}, 2} / \mathrm{N}_{\mathrm{b}, \mathrm{Rd}, 1}\right)}{\ln \left(\mathrm{f}_{\mathrm{y}, 2} / \mathrm{f}_{\mathrm{y}, 1}\right)}
$$


The power d may subsequently be determined from Equation (22) by considering two columns of differing cross-sectional area $A_{1}$ and $A_{2}$, assuming that the section second moment of area $I$ is approximately proportional to $\mathrm{A}^{2}$, giving $\frac{\mathrm{N}_{\mathrm{cr}, 1}}{\mathrm{~N}_{\mathrm{cr}, 2}} \cong\left(\frac{\mathrm{A}_{1}}{\mathrm{~A}_{2}}\right)^{2}$.

$$
\mathrm{d}=\frac{\ln \left(\mathrm{N}_{\mathrm{b}, \mathrm{Rd}, 2} / \mathrm{N}_{\mathrm{b}, \mathrm{Rd}, 1}\right)-\mathrm{c} \ln \left(\mathrm{f}_{\mathrm{y}, 2} / \mathrm{f}_{\mathrm{y}, 1}\right)}{\ln \left(\mathrm{A}_{2} / \mathrm{A}_{1}\right)}
$$

The model parameters c and d were evaluated for each test data using Equations (21) and (22), respectively by considering a small increase in the variable being changed, i.e. taking $\mathrm{f}_{\mathrm{y}, 2}=1.001 \mathrm{f}_{\mathrm{y}, 1}$ and $\mathrm{A}_{2}=1.001 \mathrm{~A}_{1}$. The relationship between the two powers $\mathrm{c}$ and $\mathrm{d}$ and the non-dimensional slenderness $\bar{\lambda}$ has been plotted in Figure 3. The values of the $\mathrm{c}$ and $\mathrm{d}$ parameters were calculated based on a plateau length of $\bar{\lambda}_{0}=0.4$ and imperfection factor of $\alpha=0.49$, which correspond to the buckling curve specified in EN 1993-1-4 [1] for cold-formed open sections and hollow sections (welded and seamless). At low slenderness values, $\bar{\lambda}_{0} \leq 0.4$, column capacity is limited by the cross-section resistance which is controlled by the material yield strength $\mathrm{f}_{\mathrm{y}}$ and the cross-sectional area $\mathrm{A}$, as presented in Equation (15), and therefore $\mathrm{c}=\mathrm{d}=1$. Note that in this instance, Equation (7) simplifies to Equation (8). At higher slenderness values, $\bar{\lambda}_{0}>0.4$, the column buckling load $\mathrm{N}_{\mathrm{b}, \mathrm{Rd}}$ approaches the elastic buckling load $\mathrm{N}_{\mathrm{cr}}$, which is independent of $\mathrm{f}_{\mathrm{y}}$, but dependent on the section geometry; hence the parameter $\mathrm{c}$ approaches zero and $\mathrm{N}_{\mathrm{b}, \mathrm{Rd}}$ will only depend on the geometric properties and may be expressed as $\mathrm{N}_{\mathrm{b}, \mathrm{Rd}}=\mathrm{kf}_{\mathrm{y}}{ }^{0} \mathrm{~A}^{\mathrm{d}}$. It is shown in Figure 3 that $\mathrm{d}$ approaches a value of 2.0 with increasing member slenderness $\bar{\lambda}$, which coincides with the elastic critical buckling load $\mathrm{N}_{\mathrm{cr}}$ considering that the second moment of area I was taken as approximately proportional to $\mathrm{A}^{2}$.

In addition, owing to the complex form of the flexural buckling resistance formulation provided in EN 19931-4 [1], the $\mathrm{V}_{\mathrm{rt}}$ parameter, used to allow for the variability of the material and geometric basic variables, was determined from Equation (7). This allows for the varying degree of the influence of the basic variables $\mathrm{f}_{\mathrm{y}}$ and $\mathrm{A}$ at different values of member slenderness to be taken into account. Adopting Equation (7), $\mathrm{V}_{\mathrm{rt}}$ may be determined from: 


$$
\begin{aligned}
\mathrm{V}_{\mathrm{rt}}=\frac{\operatorname{VAR}\left[\mathrm{g}_{\mathrm{rt}}(\underline{X})\right]}{\mathrm{g}_{\mathrm{rt}}^{2}\left(\underline{X}_{\mathrm{m}}\right)} \cong & \frac{1}{\mathrm{~g}_{\mathrm{rt}}^{2}\left(\underline{X}_{\mathrm{m}}\right)} \cdot \sum_{\mathrm{i}=1}^{\mathrm{j}}\left(\frac{\partial \mathrm{g}_{\mathrm{rt}}}{\partial \mathrm{x}_{\mathrm{i}}} \sigma_{\mathrm{i}}\right)^{2} \\
& =\frac{1}{\mathrm{~g}_{\mathrm{rt}}^{2}\left(\underline{X}_{\mathrm{m}}\right)}\left[\left(\frac{\partial \mathrm{g}_{\mathrm{rt}}}{\partial \mathrm{f}_{\mathrm{y}}} \sigma_{\mathrm{f}_{\mathrm{y}}}\right)^{2}+\left(\frac{\partial \mathrm{g}_{\mathrm{rt}}}{\partial \mathrm{A}} \sigma_{\mathrm{A}}\right)^{2}\right] \\
& =\frac{1}{\mathrm{~g}_{\mathrm{rt}}^{2}\left(\underline{X}_{\mathrm{m}}\right)}\left[\left(\mathrm{kcf} \mathrm{f}_{\mathrm{y}}^{\mathrm{c}-1} \mathrm{~A}^{\mathrm{d}} \sigma_{\mathrm{f}_{\mathrm{y}}}\right)^{2}+\left(\mathrm{kdf}_{\mathrm{y}}^{\mathrm{c}} \mathrm{A}^{\mathrm{d}-1} \sigma_{\mathrm{A}}\right)^{2}\right] \\
& =\frac{1}{\mathrm{~g}_{\mathrm{rt}}^{2}\left(\underline{X}_{\mathrm{m}}\right)}\left[\left(\mathrm{kc} \frac{\mathrm{f}_{\mathrm{y}}^{\mathrm{c}}}{\mathrm{f}_{\mathrm{y}}} \mathrm{A}^{\mathrm{d}} \sigma_{\mathrm{f}_{\mathrm{y}}}\right)^{2}+\left(\mathrm{kdf} \mathrm{f}_{\mathrm{y}}^{\mathrm{c}} \frac{\mathrm{A}^{\mathrm{d}}}{\mathrm{A}} \sigma_{\mathrm{A}}\right)^{2}\right] \\
& =\frac{1}{\mathrm{~g}_{\mathrm{rt}}^{2}\left(\underline{X}_{\mathrm{m}}\right)}\left[\left(\mathrm{kc} \frac{\mathrm{f}_{\mathrm{y}, \mathrm{m}}^{\mathrm{c}}}{\mathrm{f}_{\mathrm{y}, \mathrm{m}}} \mathrm{A}_{\mathrm{m}}^{\mathrm{d}} \sigma_{\mathrm{f}_{\mathrm{y}}, \mathrm{m}}\right)^{2}+\left(\mathrm{kdf} \mathrm{f}_{\mathrm{y}, \mathrm{m}}^{\mathrm{c}} \frac{\mathrm{A}_{\mathrm{m}}^{\mathrm{d}}}{\mathrm{A}_{\mathrm{m}}} \sigma_{\mathrm{A}, \mathrm{m}}\right)^{2}\right] \\
& =\frac{\mathrm{g}_{\mathrm{rt}}^{2}\left(\underline{X}_{\mathrm{m}}\right)}{\mathrm{g}_{\mathrm{rt}}^{2}\left(\underline{X}_{\mathrm{m}}\right)}\left[\left(\mathrm{c} \frac{\sigma_{\mathrm{f}}, \mathrm{m}}{\mathrm{f}_{\mathrm{y}, \mathrm{m}}}\right)^{2}+\left(\mathrm{d} \frac{\sigma_{\mathrm{A}, \mathrm{m}}}{\mathrm{A}_{\mathrm{m}}}\right)^{2}\right]=\left(\mathrm{c} \mathrm{V}_{\mathrm{f}_{\mathrm{y}}}\right)^{2}+\left(\mathrm{dV} \mathrm{V}_{\mathrm{A}}\right)^{2}
\end{aligned}
$$

where, $\mathrm{g}_{\mathrm{rt}}(\underline{\mathrm{X}})_{\mathrm{m}}$ and $\operatorname{VAR}\left[\mathrm{g}_{\mathrm{rt}}(\underline{\mathrm{X}})\right]$ are the mean and variance of the resistance function $\mathrm{g}_{\mathrm{rt}}(\mathrm{X})$, respectively, $\sigma_{\mathrm{f}_{\mathrm{y}}}$ and $\sigma_{\mathrm{A}}$ are the standard deviations of the yield strength and the cross-sectional area, respectively, $\mathrm{f}_{\mathrm{y}, \mathrm{m}}$ and $\mathrm{A}_{\mathrm{m}}$ are the mean values of the yield strength and cross-sectional area, respectively and $\mathrm{V}_{\mathrm{f}_{\mathrm{y}}}$ and $\mathrm{V}_{\mathrm{A}}$ are the coefficient of variation of the yield strength and the cross-sectional area respectively.

Flexural buckling test data collected from [15, 16, 18-20, 26, 27, 30, 31, 40, 41], were analysed following the above described modified approach, and values of the partial factor $\gamma_{M 1}$ for each test specimen were determined. From the least squares regression of the individual values obtained, an overall $\gamma_{M 1}$ value was subsequently determined for each stainless steel type considered - see Equation (24).

$$
\gamma_{\mathrm{M} 1}=\frac{\sum_{\mathrm{i}=1}^{\mathrm{n}} \mathrm{r}_{\mathrm{n}, \mathrm{i}}^{2}}{\sum_{\mathrm{i}=1}^{\mathrm{n}} \mathrm{r}_{\mathrm{n}, \mathrm{i}} \mathrm{r}_{\mathrm{d}, \mathrm{i}}}
$$

where, $r_{n, i}$ is the nominal resistance, based on the EN 1993-1-4 [1] flexural buckling design equation and a nominal $f_{y}$ value, and $r_{d, i}$ is the design resistance from Equation (9), both evaluated for each test specimen. The nominal yield strength may be taken as the minimum specified yield strength, provided in EN 10088-4 [9]. However, this approach was considered unsatisfactory in the analyses carried out in this paper, as the minimum specified strength may not be representative of the nominal strength of the material in the test programme considered, resulting in overly conservative partial factors. Therefore, the nominal strength in this study was taken as the mean strength, from measured test data, reduced by the relevant over-strength factor, e.g. $f_{y, n o m}=f_{y, \text { mean }} /$ (overstrength factor). A summary of the key results of the reliability analysis is presented in Table 9 . 
Values of the attained partial factors $\gamma_{\mathrm{M} 1}$ that are greater than 1.1 indicate that the current EN 1993-1-4 [1] column buckling curve fails to meet the Eurocode reliability requirements. For SHS/RHS columns, the results indicate that a slightly lower buckling curve may be required; a similar conclusion was reached for the case of ferritic stainless steels in [16], where alternative lower buckling curves were proposed. Considering that the scatter of the test data is not particularly high (see Figure 4), and also the relatively large number of test results in this category, it is unlikely that this result would change if further testing was carried out. Therefore, it is recommended that lower buckling curves for SHS/RHS members are developed. The results of Table 9 also suggest that the current provisions for austenitic circular hollow sections (CHS) are unsafe. The reason for this result can be seen in Figure 2, where between slenderness values of 0.2 and 0.6 , several data points are substantially below the buckling curve.

\subsubsection{Torsional-flexural buckling}

The EN 1993-1-4 [1] design equation for torsional-flexural buckling resistance is of the same form as the flexural buckling formulation, presented in Equations (17) and (18). The member slenderness $\bar{\lambda}$ is however defined based on the elastic buckling load for the torsional-flexural buckling mode, as given in Equations (25). A single imperfection factor $\alpha=0.34$ and limiting slenderness $\bar{\lambda}_{0}=0.2$ is recommended for all stainless steel cross-section types.

$$
\bar{\lambda}=\sqrt{\frac{\mathrm{Af}_{\mathrm{y}}}{\mathrm{N}_{\mathrm{cr}, \mathrm{TF}}}}
$$

where $\mathrm{N}_{\mathrm{cr}, \mathrm{TF}}$ is the elastic buckling load for torsional-flexural buckling mode.

Test results on stainless steel compression members failing by torsional-flexural buckling are relatively limited. The available test data were collected from a single source [42], and $\gamma_{\mathrm{M} 1}$ values were evaluated using a similar procedure to that outlined in Section 4.2.1 for flexural buckling, though with $\mathrm{d}=1$ in Equation (19), due to the added complexity of the torsional-flexural buckling equations. The results of the reliability analysis are summarised in Table 10, where the need for a higher $\gamma_{\mathrm{M} 1}$ value than the current value of 1.1 or a lower buckling curve is indicated when designing for torsional-flexural buckling. Noting that a lower torsional-flexural buckling curve, with $\alpha=0.49$ and $\bar{\lambda}_{0}=0.2$, is used in EN 1993-1-1 for the case of carbon steel members, it is recommended that a lower curve should also be considered for stainless steel members, and a numerical study into this issue is currently underway. 


\subsubsection{Lateral-torsional buckling}

EN 1993-1-4 [1] defines the lateral-torsional buckling resistance of laterally unrestrained beams through Equation (26), where $\mathrm{W}_{\mathrm{y}}$ is the major axis section modulus, taken as the plastic section modulus $\mathrm{W}_{\mathrm{pl}, \mathrm{y}}$ for Class 1 and 2 sections, the elastic section modulus $W_{\mathrm{el}, \mathrm{y}}$ for Class 3 sections and effective section modulus $\mathrm{W}_{\text {eff,y }}$ for Class 4 sections.

$$
\mathrm{M}_{\mathrm{b}, \mathrm{Rd}}=\frac{\chi_{\mathrm{LT}} \mathrm{W}_{\mathrm{y}} \mathrm{f}_{\mathrm{y}}}{\gamma_{\mathrm{M} 1}}
$$

in which the lateral-torsional buckling reduction factor $\chi_{\mathrm{LT}}$ is given by:

$\chi_{\mathrm{LT}}=\frac{1}{\phi_{\mathrm{LT}}+\sqrt{\phi_{\mathrm{LT}}^{2}-\bar{\lambda}_{\mathrm{LT}}^{2}}} \leq 1.0 \quad$ with $\quad \phi_{\mathrm{LT}}=0.5\left[1+\alpha_{\mathrm{LT}}\left(\bar{\lambda}_{\mathrm{LT}}-0.4\right)+\bar{\lambda}_{\mathrm{LT}}^{2}\right] \quad$ and $\quad \bar{\lambda}_{\mathrm{LT}}=\sqrt{\mathrm{W}_{\mathrm{y}} \mathrm{f}_{\mathrm{y}} / \mathrm{M}_{\mathrm{cr}}}$

where $\mathrm{M}_{\mathrm{cr}}$ is the elastic critical buckling moment, $\alpha_{\mathrm{LT}}$ is the imperfection factor, taken as 0.34 for for coldformed open sections and hollow sections (welded and seamless) and 0.76 for for welded open sections.

To separate the dependency of the design equation on the basic variables, the resistance function was expressed as in Equation (28), where e is determined from Equation (29), following a similar procedure as described for flexural buckling, and $\mathrm{f}$ was taken as unity. This enabled the determination of $\mathrm{V}_{\mathrm{rt}}$ for lateral-torsional buckling.

$$
\begin{gathered}
\mathrm{M}_{\mathrm{b}, \mathrm{Rd}}=\mathrm{kf}_{\mathrm{y}}^{\mathrm{e}} \mathrm{W}_{\mathrm{y}}^{\mathrm{f}} \\
\mathrm{e}=\frac{\ln \left(\mathrm{M}_{\mathrm{b}, \mathrm{Rd}, 2} / \mathrm{M}_{\mathrm{b}, \mathrm{Rd}, 1}\right)}{\ln \left(\mathrm{f}_{\mathrm{y}, 2} / \mathrm{f}_{\mathrm{y}, 1}\right)}
\end{gathered}
$$

The above described method was applied to lateral-torsional buckling test data obtained from [11, 43, 44], and a summary of the statistical analysis results is provided in Table 11. The calculated values of $\gamma_{\mathrm{M} 1}$ suggest that a higher partial factor that the current value 1.1 or a lower buckling curve is necessary for lateral-torsional buckling. The results from these tests show relatively high scatter (see Figure 5), perhaps due to the manner in which the tests were conducted, but very few points lie below the design curve and those that do are only marginally below. Hence, the current buckling curve is considered to be satisfactory. 


\subsubsection{Shear buckling}

The shear buckling resistance of stiffened and unstiffened stainless steel webs $\mathrm{V}_{\mathrm{b}, \mathrm{Rd}}$, as set out in EN 1993-1-5 [45], may be determined from Equation (30), where $\mathrm{V}_{\mathrm{bw}, \mathrm{Rd}}$ is the web shear buckling resistance and $\mathrm{V}_{\mathrm{bf}, \mathrm{Rd}}$ is the shear resistance contribution from the flanges. As the flange contribution makes up a relatively small proportion of the total shear resistance, the web contribution given by Equation (31) has been considered for the purpose of reliability analysis herein.

$$
\mathrm{V}_{\mathrm{b}, \mathrm{Rd}}=\mathrm{V}_{\mathrm{bw}, \mathrm{Rd}}+\mathrm{V}_{\mathrm{bf}, \mathrm{Rd}} \leq \frac{\eta \mathrm{f}_{\mathrm{yw}} \mathrm{h}_{\mathrm{w}} \mathrm{t}_{\mathrm{w}}}{\sqrt{3} \gamma_{\mathrm{M} 1}}
$$

where $\mathrm{f}_{\mathrm{yw}}$ is the yield strength of the web, $\eta$ is a parameter that approximates the influence of strain hardening, $h_{w}$ is the depth of the web, $t_{w}$ is the thickness of the web and $\gamma_{\mathrm{M} 1}$ is the partial safety factor.

$$
\mathrm{V}_{\mathrm{bw}, \mathrm{Rd}}=\frac{\chi_{\mathrm{w}} \mathrm{f}_{\mathrm{yw}} \mathrm{h}_{\mathrm{w}} \mathrm{t}_{\mathrm{w}}}{\sqrt{3} \gamma_{\mathrm{M} 1}}
$$

where $\chi_{\mathrm{w}}$ is the shear buckling reduction factor. The shear buckling resistance of the web may alternatively be expressed as:

$$
\mathrm{V}_{\mathrm{bw}, \mathrm{Rd}}=\mathrm{k} \tau_{\mathrm{y}, \mathrm{w}}^{\mathrm{g}} \mathrm{A}_{\mathrm{w}}^{\mathrm{h}}
$$

where $\tau_{\mathrm{yw}}$ is the yield strength of the web in shear, taken as $\mathrm{f}_{\mathrm{yw}} / \sqrt{3}$ and $\mathrm{A}_{\mathrm{w}}=\mathrm{h}_{\mathrm{w}} \mathrm{t}_{\mathrm{w}}$ are the two independent variables, and $\mathrm{k}$ is the model constant which does not depend on the other two parameters. The powers $\mathrm{g}$ and h may be determined from Equations (33) and (34), following a similar procedure to that described for the flexural buckling case.

$$
\begin{gathered}
\mathrm{g}=\frac{\ln \left(\mathrm{V}_{\mathrm{bw}, \mathrm{Rd}, 2} / \mathrm{V}_{\mathrm{bw}, \mathrm{Rd}, 1}\right)}{\ln \left(\mathrm{f}_{\mathrm{y}, 2} / \mathrm{f}_{\mathrm{y}, 1}\right)} \\
\mathrm{h}=\frac{\ln \left(\mathrm{V}_{\mathrm{bw}, \mathrm{Rd}, 2} / \mathrm{V}_{\mathrm{bw}, \mathrm{Rd}, 1}\right)-\mathrm{g} \ln \left(\mathrm{f}_{\mathrm{y}, 2} / \mathrm{f}_{\mathrm{y}, 1}\right)}{\ln \left(\mathrm{A}_{\mathrm{w}, 2} / \mathrm{A}_{\mathrm{w}, 1}\right)}
\end{gathered}
$$

A statistical evaluation based on the above described approach was performed for the collected test data from $[36,46-48]$, and the obtained results are reported in Table 12 . The relatively high scatter in the predicted resistance of the duplex test data $\mathrm{V}_{\delta}=0.134$ leads to a $\gamma_{\mathrm{M} 1}$ value of 1.19 , while for the austenitic grades the current value of 1.1 is satisfactory. 


\subsubsection{Bolted connections}

Three different failure modes, namely bolt shear failure, bolt or plate bearing failure and net section tensile failure, are recognised in EN 1993-1-4 [1] and EN 1993-1-8 [49] for the design of stainless steel bolted shear connections. The design resistance for bolt shear failure $\mathrm{F}_{\mathrm{v}, \mathrm{Rd}}$ and bolt or plate bearing failure $\mathrm{F}_{\mathrm{b}, \mathrm{Rd}}$, as set out in EN 1993-1-4 and EN 1993-1-8, are given by Equations (35) and (36), respectively. In Equation (35), $\alpha_{\mathrm{v}}$ takes a value of 0.6 or 0.5 , depending on the bolt grade and whether the shear plane passes through the threaded or unthreaded portion of the bolt, $\mathrm{f}_{\mathrm{ub}}$ is the ultimate tensile strength of the bolt, $\mathrm{A}$ is the crosssectional area of the bolt and $\gamma_{\mathrm{M} 2}$ is the partial safety factor. In Equation (36), the $\mathrm{k}_{1}$ and $\alpha_{\mathrm{b}}$ parameters account for the reduction in bearing resistance due to bolt spacing, end and edge distances and the possibility of the bolt failing in bearing rather than the plate, $f_{u}$ is the ultimate tensile strength of the connected part (which is taken as the reduced ultimate tensile strength, $\mathrm{f}_{\mathrm{u}, \mathrm{red}}=0.5 \mathrm{f}_{\mathrm{y}}+0.6 \mathrm{f}_{\mathrm{u}}$ but $\leq \mathrm{f}_{\mathrm{u}}$ ) and $\mathrm{d}$ and $\mathrm{t}$ are the bolt diameter and the thickness of the connected part, respectively. For bolted shear connections, where failure is controlled by net section tensile failure, the tensile resistance of the member $\mathrm{N}_{\mathrm{u}, \mathrm{Rd}}$ should to be evaluated according to Equation (37), where $A_{\text {net }}$ is the net cross-sectional area and $\mathrm{f}_{\mathrm{u}}$ is the ultimate tensile strength of the material and $\mathrm{k}_{\mathrm{r}}$ parameter depends on the geometry of the bolt group and the number of bolts.

$$
\begin{gathered}
\mathrm{F}_{\mathrm{v}, \mathrm{Rd}}=\frac{\alpha_{\mathrm{v}} \mathrm{f}_{\mathrm{ub}} \mathrm{A}}{\gamma_{\mathrm{M} 2}} \\
\mathrm{~F}_{\mathrm{b}, \mathrm{Rd}}=\frac{\mathrm{k}_{1} \alpha_{\mathrm{b}} \mathrm{f}_{\mathrm{u}, \mathrm{red}} \mathrm{dt}}{\gamma_{\mathrm{M} 2}} \\
\mathrm{~N}_{\mathrm{u}, \mathrm{Rd}}=\frac{\mathrm{k}_{\mathrm{r}} \mathrm{A}_{\mathrm{net}} \mathrm{f}_{\mathrm{u}}}{\gamma_{\mathrm{M} 2}}
\end{gathered}
$$

Test data on stainless steel shear connections [10], were used to assess the partial factor $\gamma_{\mathrm{M}_{2}}$ used with Equations (35), (36) and (37) in EN 1993-1-4 [1]. The results of the statistical analysis for each failure mode are reported in Table 13. Note that in the absence of suitable statistical data on stainless steel bolts, the statistical parameters used for the analysis presented in this section were based on those of the stainless steel sheet/plate products. While the obtained $\gamma_{\mathrm{M} 2}$ values are below the current value of 1.25 by a considerable margin, these are based on relatively few test data points, especially for bearing failure, and a more comprehensive physical test database is clearly needed. Numerical studies of stainless steel shear connections in $[50,51]$ have also noted the conservatism in the current Eurocode provisions, and revised design expressions 
were proposed.

\subsubsection{Welded connections}

The design resistance of a stainless steel fillet weld connection $\mathrm{F}_{\mathrm{w}, \mathrm{Rd}}$, based on the EN 1993-1-4 provisions, is given as the product of the weld design shear strength $\mathrm{f}_{\mathrm{vw}, \mathrm{Rd}}$ and the weld effective cross-sectional area, taken as the weld throat thickness a multiplied by the effective length of the weld L, as given by Equation (38). The weld design shear strength $f_{\mathrm{vw}, \mathrm{Rd}}$ is given by Equation (39) and is a function of the ultimate tensile strength of the connected parts and $\beta_{\mathrm{w}}$, which makes allowance for the material grade, but is taken as unity for stainless steel [1].

$$
\begin{gathered}
\mathrm{F}_{\mathrm{w}, \mathrm{Rd}}=\mathrm{f}_{\mathrm{vw}, \mathrm{Rd}} \mathrm{aL} \\
\mathrm{f}_{\mathrm{vw}, \mathrm{Rd}}=\frac{\mathrm{f}_{\mathrm{u}}}{\sqrt{3} \beta_{\mathrm{w}} \gamma_{\mathrm{M} 2}}
\end{gathered}
$$

Test data on fillet welded stainless steel connections obtained from [11] were analysed to assess the partial factor $\gamma_{\mathrm{M} 2}$. Values of the key statistical parameters derived from the reliability analysis of the data are reported in Table 14. A value of $\gamma_{\mathrm{M} 2}$ of slightly more than 1.25 is indicated for the austenitic material; nonetheless, it is recommended that the current $\gamma_{\mathrm{M} 2}$ value of 1.25 is maintained for welded connections. Note that data on welded stainless steel connections are relatively scarce and that future work is needed in this area.

\section{Conclusions}

A reliability assessment of the EN 1993-1-4 structural stainless steel design provisions has been carried out in this study, and the obtained results have been presented and discussed. Statistical data on material properties suitable for use in reliability analyses were derived from industrial data. For yield strength, representative over-strength values and COVs of 1.3 and 0.060 for austenitic, 1.1 and 0.030 for duplex and 1.2 and 0.045 for ferritic stainless steels were established, while for the ultimate tensile strength, an overstrength value of 1.1 for all stainless steel grades and COVs of 0.035 for the austenitic and duplex grades and 0.05 for the ferritic grade were proposed. Based on the database of sections considered in this study, a COV value of 0.05 was adopted to represent the variability of the geometric properties. Analysis of crosssection compression and in-plane bending test results showed that the current $\gamma_{\mathrm{M} 0}$ value of 1.1 given in EN 1993-1-4 may be maintained for the section types considered, excluding CHS elements in compression, where 
revised design provisions are needed and a shorter plateau length is recommended. Column flexural buckling design rules were also assessed, and it was found that the current $\gamma_{\mathrm{M} 1}$ value of 1.1 is generally satisfactory, but some buckling curves, particularly for CHS compression members, should be revisited. For cases of torsional-flexural buckling and lateral-torsional buckling, it was recommended that the current $\gamma_{\mathrm{M} 1}=1.1$ is maintained, but a reassessment of this value needs to carried out upon generation of a more comprehensive pool of experimental data. Based on the analysis of both bolted and welded connection test results, it was recommended that no increase in the current $\gamma_{\mathrm{M} 2}$ value of 1.25 is necessary.

\section{Acknowledgements}

The authors would like to thank the European Stainless Steel Development Association Euro Inox for sponsoring the project. 


\section{Appendix A: Derivation of $V_{\text {geometry }}$ for various section shapes}

This appendix presents the method used to calculate the $\mathrm{V}_{\text {geometry }}$ parameter for the SHS/RHS, CHS and I-sections, based on the dimensional variation data presented in Tables 3, 4 and 5 in Section 3.3. The method employed is based on Equation (7), which can be expressed in the form given by Equation (40).

$$
\mathrm{V}_{\text {geometry }}^{2}=\sum_{\mathrm{i}=1}^{\mathrm{n}}\left(\mathrm{w}_{\mathrm{i}} \mathrm{V}_{\mathrm{i}}\right)^{2}
$$

where $w_{i}$ is the weighting factor for geometric variable $i$, determined from $w_{i}=\left(\frac{\partial g_{r t}}{\partial x_{i}} \mu_{i}\right) / g_{r t}\left(\underline{X}_{m}\right)$ and $V_{i}$ is the $\mathrm{COV}$ for geometric variable $\mathrm{i}$. In the expression for $\mathrm{w}_{\mathrm{i}}, \mu_{\mathrm{i}}$ is the mean value of variable $\mathrm{X}_{\mathrm{i}}$.

\subsection{Compression resistance}

Using Equation (40):

RHS/SHS Cross-section compression resistance: $\mathrm{N}_{\mathrm{c}, \mathrm{Rd}}=\mathrm{Af}_{\mathrm{y}}$

Cross-sectional area: $\mathrm{A} \approx 2 \mathrm{t}(\mathrm{b}+\mathrm{d})$

$\partial \mathrm{A} / \partial \mathrm{b}=2 \mathrm{t}$ and $\mathrm{w}_{\mathrm{b}}=\frac{2 \mathrm{t}}{\mathrm{A}} \times \mathrm{b}$

$\partial \mathrm{A} / \partial \mathrm{d}=2 \mathrm{t}$ and $\mathrm{w}_{\mathrm{d}}=\frac{2 \mathrm{t}}{\mathrm{A}} \times \mathrm{d}$

$\partial \mathrm{A} / \partial \mathrm{t}=2(\mathrm{~b}+\mathrm{d})$ and $\mathrm{w}_{\mathrm{t}}=\frac{2(\mathrm{~b}+\mathrm{d})}{\mathrm{A}} \times \mathrm{t}$

$\mathrm{V}_{\mathrm{A}}=\sqrt{\left(\mathrm{w}_{\mathrm{b}} \mathrm{V}_{\mathrm{b}}\right)^{2}+\left(\mathrm{w}_{\mathrm{d}} \mathrm{V}_{\mathrm{d}}\right)^{2}+\left(\mathrm{w}_{\mathrm{t}} \mathrm{V}_{\mathrm{t}}\right)^{2}}$

CHS Cross-section compression resistance: $\mathrm{N}_{\mathrm{c}, \mathrm{Rd}}=\mathrm{Af}_{\mathrm{y}}$

The cross-sectional area: $\mathrm{A} \approx \frac{\pi \mathrm{D}^{2}}{4}-\frac{\pi(\mathrm{D}-2 \mathrm{t})^{2}}{4}$

$\partial \mathrm{A} / \partial \mathrm{D}=2 \mathrm{t}$ and $\mathrm{w}_{\mathrm{D}}=\frac{2 \mathrm{t}}{\mathrm{A}} \times \mathrm{D}$

$\partial \mathrm{A} / \partial \mathrm{t}=\pi(\mathrm{D}-2 \mathrm{t})$ and $\mathrm{w}_{\mathrm{t}}=\frac{\pi(\mathrm{D}-2 \mathrm{t})}{\mathrm{A}} \times \mathrm{t}$

$\mathrm{V}_{\mathrm{A}}=\sqrt{\left(\mathrm{w}_{\mathrm{D}} \mathrm{V}_{\mathrm{D}}\right)^{2}+\left(\mathrm{w}_{\mathrm{t}} \mathrm{V}_{\mathrm{t}}\right)^{2}}$

I-sections $\quad$ Cross-section compression resistance: $\mathrm{N}_{\mathrm{c}, \mathrm{Rd}}=\mathrm{Af}_{\mathrm{y}}$

The cross-sectional area: $A \approx \mathrm{t}_{\mathrm{w}}\left(\mathrm{h}-2 \mathrm{t}_{\mathrm{f}}\right)+2 \mathrm{bt}_{\mathrm{f}}$

$\partial \mathrm{A} / \partial \mathrm{h}=\mathrm{t}_{\mathrm{w}}$ and $\mathrm{w}_{\mathrm{h}}=\frac{\mathrm{t}_{\mathrm{w}}}{\mathrm{A}} \times \mathrm{h}$

$\partial \mathrm{A} / \partial \mathrm{b}=2 \mathrm{t}_{\mathrm{f}}$ and $\mathrm{w}_{\mathrm{b}}=\frac{2 \mathrm{t}_{\mathrm{f}}}{\mathrm{A}} \times \mathrm{b}$

$\partial \mathrm{A} / \partial \mathrm{t}_{\mathrm{w}}=\mathrm{h}-2 \mathrm{t}_{\mathrm{f}}$ and $\mathrm{w}_{\mathrm{t}_{\mathrm{w}}}=\frac{\mathrm{h}-2 \mathrm{t}_{\mathrm{f}}}{\mathrm{A}} \times \mathrm{t}_{\mathrm{w}}$

$\partial \mathrm{A} / \partial \mathrm{t}_{\mathrm{f}}=2\left(\mathrm{~b}+\mathrm{t}_{\mathrm{w}}\right) \operatorname{andw}_{\mathrm{t}_{\mathrm{f}}}=\frac{2\left(\mathrm{~b}+\mathrm{t}_{\mathrm{w}}\right)}{\mathrm{A}} \times \mathrm{t}_{\mathrm{f}}$

$\mathrm{V}_{\mathrm{A}}=\sqrt{\left(\mathrm{w}_{\mathrm{h}} \mathrm{V}_{\mathrm{h}}\right)^{2}+\left(\mathrm{w}_{\mathrm{b}} \mathrm{V}_{\mathrm{b}}\right)^{2}+\left(\mathrm{w}_{\mathrm{t}_{\mathrm{w}}} \mathrm{V}_{\mathrm{t}_{\mathrm{w}}}\right)^{2}+\left(\mathrm{w}_{\mathrm{t}_{\mathrm{f}}} \mathrm{V}_{\mathrm{t}_{\mathrm{f}}}\right)^{2}}$ 


\subsection{Bending resistance}

Using Equation (40):

RHS/SHS Cross-section bending resistance: $\mathrm{M}_{\mathrm{c}, \mathrm{Rd}}=\mathrm{W}_{\mathrm{pl}} \mathrm{f}_{\mathrm{y}}$

The cross-section plastic modulus: $\mathrm{W}_{\mathrm{pl}} \approx \frac{\mathrm{bd}^{2}}{4}-\frac{(\mathrm{b}-2 \mathrm{t})(\mathrm{d}-2 \mathrm{t})^{2}}{4}$

$\partial \mathrm{W}_{\mathrm{pl}} / \partial \mathrm{b}=2 \mathrm{dt}-\mathrm{t}^{2}$ and $\mathrm{w}_{\mathrm{b}}=\frac{\mathrm{dt}-\mathrm{t}^{2}}{\mathrm{~W}_{\mathrm{pl}}} \times \mathrm{b}$

$\partial \mathrm{W}_{\mathrm{pl}} / \partial \mathrm{d}=(\mathrm{b}+\mathrm{d}) \mathrm{t}-2 \mathrm{t}^{2}$ and $\mathrm{w}_{\mathrm{d}}=\frac{(\mathrm{b}+\mathrm{d}) \mathrm{t}-2 \mathrm{t}^{2}}{\mathrm{~W}_{\mathrm{pl}}} \times \mathrm{d}$

$\partial \mathrm{W}_{\mathrm{pl}} / \partial \mathrm{t}=6 \mathrm{t}^{2}-4 \mathrm{dt}-2 \mathrm{bt}+\mathrm{d}^{2} / 2+\mathrm{bd}$ and $\mathrm{w}_{\mathrm{t}}=\frac{6 \mathrm{t}^{2}-4 \mathrm{dt}-2 \mathrm{bt}+\mathrm{d}^{2} / 2+\mathrm{bd}}{\mathrm{W}_{\mathrm{pl}}} \times \mathrm{t}$

$\mathrm{V}_{\mathrm{W}_{\mathrm{pl}}}=\sqrt{\left(\mathrm{w}_{\mathrm{b}} \mathrm{V}_{\mathrm{b}}\right)^{2}+\left(\mathrm{w}_{\mathrm{d}} \mathrm{V}_{\mathrm{d}}\right)^{2}+\left(\mathrm{w}_{\mathrm{t}} \mathrm{V}_{\mathrm{t}}\right)^{2}}$

CHS Cross-section compression resistance: $\mathrm{M}_{\mathrm{c}, \mathrm{Rd}}=\mathrm{W}_{\mathrm{pl}} \mathrm{f}_{\mathrm{y}}$

The cross-section plastic modulus: $\mathrm{W}_{\mathrm{pl}} \approx \frac{\mathrm{D}^{3}-(\mathrm{D}-2 \mathrm{t})^{3}}{6}$

$\partial \mathrm{W}_{\mathrm{pl}} / \partial \mathrm{D}=\frac{2 \mathrm{Dt}-2 \mathrm{D}^{2}}{2}$ and $\mathrm{w}_{\mathrm{D}}=\frac{\mathrm{Dt}-\mathrm{D}^{2}}{\mathrm{~W}_{\mathrm{pl}}} \times \mathrm{D}$

$\partial \mathrm{W}_{\mathrm{pl}} / \partial \mathrm{t}=4 \mathrm{t}^{2}-4 \mathrm{Dt}+\mathrm{D}^{2}$ and $\mathrm{w}_{\mathrm{t}}=\frac{4 \mathrm{t}^{2}-4 \mathrm{Dt}+\mathrm{D}^{2}}{\mathrm{~W}_{\mathrm{pl}}} \times \mathrm{t}$

$\mathrm{V}_{\mathrm{W}_{\mathrm{pl}}}=\sqrt{\left(\mathrm{w}_{\mathrm{D}} \mathrm{V}_{\mathrm{D}}\right)^{2}+\left(\mathrm{w}_{\mathrm{t}} \mathrm{V}_{\mathrm{t}}\right)^{2}}$

I-sections Cross-section compression resistance: $\mathrm{M}_{\mathrm{c}, \mathrm{Rd}}=\mathrm{W}_{\mathrm{pl}} \mathrm{f}_{\mathrm{y}}$

The cross-section plastic modulus: $\mathrm{W}_{\mathrm{pl}} \approx_{\mathrm{f}}\left(\mathrm{h}-\mathrm{t}_{\mathrm{f}}\right)+\frac{\mathrm{t}_{\mathrm{w}}\left(\mathrm{h}-2 \mathrm{t}_{\mathrm{f}}\right)^{2}}{4}$

$\partial \mathrm{W}_{\mathrm{pl}} / \partial \mathrm{h}=\frac{-\left(2 \mathrm{t}_{\mathrm{w}}-2 \mathrm{~b}\right) \mathrm{t}_{\mathrm{f}}-\mathrm{ht}_{\mathrm{w}}}{2}$ and $\mathrm{w}_{\mathrm{h}}=\frac{-\left(2 \mathrm{t}_{\mathrm{w}}-2 \mathrm{~b}\right) \mathrm{t}_{\mathrm{f}}-\mathrm{ht}_{\mathrm{w}}}{\mathrm{W}_{\mathrm{pl}}} \times \mathrm{h}$

$\partial \mathrm{W}_{\mathrm{pl}} / \partial \mathrm{b}=\mathrm{ht}_{\mathrm{f}}-\mathrm{t}_{2}^{2}$ and $\mathrm{w}_{\mathrm{b}}=\frac{\mathrm{ht}_{\mathrm{f}}-\mathrm{t}_{2}^{2}}{\mathrm{~W}_{\mathrm{pl}}} \times \mathrm{b}$

$\partial \mathrm{W}_{\mathrm{pl}} / \partial \mathrm{t}_{\mathrm{w}}=4 \mathrm{t}_{\mathrm{f}}^{2}-4 \mathrm{ht}_{\mathrm{f}}+\mathrm{h}^{2}$ and $\mathrm{w}_{\mathrm{t}_{\mathrm{w}}}=\frac{4 \mathrm{t}_{\mathrm{f}}^{2}-4 \mathrm{ht}_{\mathrm{f}}+\mathrm{h}^{2}}{\mathrm{w}_{\mathrm{pl}}} \times \mathrm{t}_{\mathrm{w}}$

$\partial \mathrm{W}_{\mathrm{pl}} / \partial \mathrm{t}_{\mathrm{f}}=\left(2 \mathrm{t}_{\mathrm{w}}-2 \mathrm{~b}\right) \mathrm{t}_{\mathrm{f}}-\mathrm{ht}_{\mathrm{w}}+\mathrm{hb}$ and $\mathrm{w}_{\mathrm{t}_{\mathrm{f}}}=\frac{\left(2 \mathrm{t}_{\mathrm{w}}-2 \mathrm{~b}\right) \mathrm{t}_{\mathrm{f}}-\mathrm{ht}_{\mathrm{w}}+\mathrm{hb}}{\mathrm{W}_{\mathrm{pl}}} \times \mathrm{t}_{\mathrm{f}}$

$\mathrm{V}_{\mathrm{W}_{\mathrm{pl}}}=\sqrt{\left(\mathrm{w}_{\mathrm{h}} \mathrm{V}_{\mathrm{h}}\right)^{2}+\left(\mathrm{w}_{\mathrm{b}} \mathrm{V}_{\mathrm{b}}\right)^{2}+\left(\mathrm{w}_{\mathrm{t}_{\mathrm{w}}} \mathrm{V}_{\mathrm{t}_{\mathrm{w}}}\right)^{2}+\left(\mathrm{w}_{\mathrm{t}_{\mathrm{f}}} \mathrm{V}_{\mathrm{t}_{\mathrm{f}}}\right)^{2}}$

\section{References}

[1] EN 1993-1-4 . Eurocode 3: Design of steel structures - Part 1-4: General rules - Supplementary rules for stainless steels. Brussels: European Committee for Standardization; 2006.

[2] EN 1990 . Eurocode - Basis of structural design. Brussels: European Committee for Standardization; 2002.

[3] Sedlacek G, Kraus O. Use of safety factors for the design of steel structures according to the Eurocodes. Engineering Failure Analysis 2007;14(3):434-41.

[4] Groth HL, Johansson RE. Statics of the mechanical strength of stainless steels - sheet. In: Proceedings of nordic symposium on mechanical properties of stainless steel. Sweden; 1990,. 
[5] Leffler B. A statical study of the mechanical properties of hot rolled stainless steel. In: Proceedings of nordic symposium on mechanical properties of stainless steel. Sweden; 1990,.

[6] Outokumpu . Standard Cr-Ni stainless steels. Tech. Rep. 1197 EN-GB; Sweden; 2005.

[7] Outokumpu . Standard Cr-Ni-Mo stainless steels. Tech. Rep. 1198 EN-GB; Sweden; 2005.

[8] Outokumpu . Duplex stainless steel. Tech. Rep. 1008 EN-GB:6; Sweden; 2008.

[9] EN 10088-4 . Stainless steels Part 4: Technical delivery conditions for sheet/plate and strip of corrosion resisting steels for construction purposes. European Committee for Standardization; 2009.

[10] Byfield MP, Nethercot DA. An analysis of the true bending strength of steel beams. Proceedings of the Institution of Civil Engineeris - Structures and Buildings 1988;128:188-97.

[11] Baddoo NR, Gardner L. Final Report. ECSC project - Development of the use of stainless steel in construction. Tech. Rep. RT810, Contract No. 7210 SA/ 842; The Steel Construction Institute, UK; 2000.

[12] AISC . Design Guide 27: Structural Stainless Steel. American Institute of Steel Construction; 2013.

[13] Gardner L, Theofanous M. Discrete and continuous treatment of local buckling in stainless steel elements. Journal of Constructional Steel Research 2008;64(11):1207 -16.

[14] Gardner L, Nethercot DA. Experiments on stainless steel hollow sections - Part 1: Material and crosssectional behaviour. Journal of Constructional Steel Research 2004;60(9):1291 -318.

[15] Theofanous M, Gardner L. Testing and numerical modelling of lean duplex stainless steel hollow section columns. Engineering Structures 2009;31(12):3047 -58.

[16] Afshan S, Gardner L. Experimental study of cold-formed ferritic stainless steel hollow sections. Journal of Structural Engineering - ASCE 2013;139(5):717 -28.

[17] Gardner L, Talja A, Baddoo NR. Structural design of high-strength austenitic stainless steel. ThinWalled Structures 2006;44(5):517 -28.

[18] Young B, Liu Y. Experimental investigation of cold-formed stainless steel columns. Journal of Structural Engineering - ASCE 2003;129(2):169 -76.

[19] Liu Y, Young B. Buckling of stainless steel square hollow section compression members. Journal of Constructional Steel Research 2003;59(2):165 -77.

[20] Young B, Lui WM. Tests of cold-formed high strength stainless steel compression members. Thin-Walled Structures 2006;44(2):224 -34. 
[21] Young B, Lui WM. Behavior of cold-formed high strength stainless steel sections. Journal of Structural Engineering - ASCE 2005;131(11):1738 -45.

[22] Rasmussen KJR, Hancock GJ. Design of cold-formed stainless steel tubular members. I: Columns. Journal of Structural Engineering - ASCE 1993;119(8):2349-67.

[23] Kuwamura H. Local buckling of thin-walled stainless steel members. Steel Structures 2003;3(3):191 201.

[24] Huang Y, Young B. Material properties of cold-formed lean duplex stainless steel sections. Thin-Walled Structures 2012;54(0):72 - 81.

[25] Saliba N, Gardner L. Cross-section stability of lean duplex stainless steel welded I:-sections. Journal of Constructional Steel Research 2013;80(0):1 - 14 .

[26] Young B, Hartono W. Compression tests of stainless steel tubular members. Journal of Structural Engineering - ASCE 2002;128(6):754-61.

[27] Burgan BA, Baddoo NR, Gilsenan K. Structural design of stainless steel members - comparison between Eurocode 3, part 1.4 and test results. Journal of Constructional Steel Research 2000;54(1):51-73.

[28] Bardi F, Kyriakides S. Plastic buckling of circular tubes under axial compression - Part I: Experiments. International Journal of Mechanical Sciences 2006;48(8):830-41.

[29] Mirambell E, Real E. On the calculation of deflections in structural stainless steel beams: an experimental and numerical investigation. Journal of Constructional Steel Research 2000;54(1):109 -33.

[30] Talja A, Salmi P. Design of stainless steel RHS beams, columns and beam-columns. Tech. Rep. 1619; VTT building technology, Finland.; 1995.

[31] Gardner L, Nethercot DA. Experiments on stainless steel hollow sections - Part 2: Member behaviour of columns and beams. Journal of Constructional Steel Research 2004;60(9):1319 -32.

[32] Zhou F, Young B. Tests of cold-formed stainless steel tubular flexural members. Thin-Walled Structures 2005;43(9):1325 -37.

[33] Theofanous M, Gardner L. Experimental and numerical studies of lean duplex stainless steel beams. Journal of Constructional Steel Research 2010;66(6):816 -25.

[34] Rasmussen KJR, Hancock GJ. Design of cold-formed stainless steel tubular members. II: Beams. Journal of Structural Engineering - ASCE 1993;119(8):2368 -86. 
[35] Theofanous M, Saliba N, Zhao O, Gardner L. Ultimate response of stainless steel continuous beams. Thin-Walled Structures 2010;83:115-27.

[36] Real E. Aportaciones al estudio del comportamiento en flexin de estructuras de acero inoxidable. Ph.D. thesis; Departamento de Ingeniera de la Construccin, UPC-ETSECCP.; Spain; 2001.

[37] Kiymaz G. Strength and stablity criterial for thin-walled stainless steel circular hollow section members under bending. Thin-Walled Structures 2005;43(10):1534-49.

[38] Talja A. Test report on welded I and CHS beams, columns and beam-columns. Tech. Rep.; Technical Research Centre of Finland (VTT); Finland; 1997.

[39] Theofanous M, Chan TM, Gardner L. Structural response of stainless steel oval hollow section compression members. Engineering Structures 2009;31(4):922-34.

[40] Ala-Outinen T. Stainless steel in fire (SSIF). Work package 3: Members with class 4 cross-sections in fire. Tech. Rep. RFS-CR-04048.; The Steel Construction Institute, UK; 2007.

[41] SCI . Tests on stainless steel materials. Tech. Rep. SCI-RT-251; The Steel Construction Institute, UK.; 1991.

[42] Van den Berg GJ. The torsional flexural buckling strength of cold-formed stainless steel columns. Ph.D. thesis; Faculty of Engineering, Rand Afrikaans University; 1988.

[43] Bredenkamp PJ, van den Berg GJ. The strength of stainless steel built-up I-section columns. Journal of Constructional Steel Research 1995;34(2-3):131-44.

[44] van Wyk ML, van den Berg GJ, van der Merwe P. The lateral torsional buckling strength of doubly symmetric stainless steel beams. Tech. Rep. MD-58; Faculty of Engineering, Rand Afrikaans University; 1990.

[45] EN 1993-1-5 . Eurocode 3 - Design of steel structures - Part 1-5: Plated structural elements. Brussels: European Committee for Standardization; 2006.

[46] Saliba N, Real E, Gardner L. Shear design recommendations for stainless steel plate girders. Engineering Structures 2014;59:220-8.

[47] Estrada I, Real E, Mirambell E. Shear resistance in stainless steel plate girders with transverse and longitudinal stiffening. Journal of Constructional Steel Research 2008,;64(11):1239-54.

[48] Unosson E, Olsson A. Stainless steel girders - resistance to concentrated loads and shear. In: Proceedings of stainless steel in structures - International Experts Seminar. The Steel Construction Institute; 2003,. 
[49] EN 1993-1-8 . Eurocode 3: Design of steel structures - Part 1-8: Design of joints. Brussels: European Committee for Standardization; 2005.

[50] Salih EL, Gardner L, Nethercot DA. Bearing failure in stainless steel bolted connections. Engineering Structures 2011;33(2):549-62.

[51] Salih EL, Gardner L, Nethercot DA. Numerical investigation of net section failure in stainless steel bolted connections. Journal of Constructional Steel Research 2010;66(12):1455-66. 
Table 1: Statistical data on material yield strength

\begin{tabular}{|c|c|c|c|c|c|c|c|c|c|}
\hline $\begin{array}{l}\text { Material } \\
\text { type }\end{array}$ & $\begin{array}{l}\text { Product } \\
\text { type }\end{array}$ & Source & $\begin{array}{l}\text { No. of } \\
\text { tests } n\end{array}$ & $\begin{array}{l}\text { Thickness } \\
\text { range (mm) }\end{array}$ & $\begin{array}{l}\mathrm{f}_{\mathrm{y}, \text { mean }} \\
\left(\mathrm{N} / \mathrm{mm}^{2}\right)\end{array}$ & $\begin{array}{l}\sigma \\
\left(\mathrm{N} / \mathrm{mm}^{2}\right)\end{array}$ & $\mathrm{COV}$ & $\frac{f_{y, \text { mean }}}{f_{y, \text { min }}}$ & $\frac{f_{y, k}}{f_{y, \text { min }}}$ \\
\hline \multirow{9}{*}{ Austenitic } & \multirow{2}{*}{$\mathrm{C}$} & {$[4]$} & 2572 & $2.49-6.35$ & 312 & 15.2 & 0.049 & 1.34 & 1.24 \\
\hline & & Producer & - & - & 314 & 22.9 & 0.073 & 1.34 & 1.19 \\
\hline & \multirow{2}{*}{$\mathrm{H}$} & {$[6,7]$} & - & 4.0 & 290 & - & - & 1.37 & - \\
\hline & & Producer & - & - & 326 & 25.3 & 0.078 & 1.54 & 1.35 \\
\hline & \multirow{4}{*}{$\mathrm{P}$} & {$[5]$} & $>3000$ & $5.0-50$ & 294 & 20.6 & 0.070 & 1.38 & 1.23 \\
\hline & & {$[6,7]$} & - & 15.0 & 283 & - & - & 1.33 & - \\
\hline & & Producer & 1368 & - & 309 & 33.0 & 0.107 & 1.44 & 1.20 \\
\hline & & Producer & - & - & 293 & 28.8 & 0.099 & 1.40 & 1.19 \\
\hline & Average & & & & 308 & & & 1.41 & 1.23 \\
\hline \multirow{12}{*}{ Duplex } & \multirow{5}{*}{$\mathrm{C}$} & {$[4]$} & 239 & $2.49-6.35$ & 586 & 26.5 & 0.045 & 1.17 & 1.09 \\
\hline & & {$[8]$} & - & 1.0 & 650 & - & - & 1.27 & - \\
\hline & & Producer & 5747 & $0.4-3.5$ & 631 & 27.3 & 0.043 & 1.28 & 1.19 \\
\hline & & Producer & - & - & 610 & 30.9 & 0.052 & 1.26 & 1.16 \\
\hline & & Producer & - & $<6.4$ & 550 & 7.5 & 0.014 & 1.04 & 1.01 \\
\hline & \multirow{3}{*}{$\mathrm{H}$} & {$[8]$} & - & 4.0 & 595 & - & - & 1.27 & - \\
\hline & & Producer & - & - & 591 & 49.0 & 0.087 & 1.33 & 1.16 \\
\hline & & Producer & - & $<10$ & 549 & 12.2 & 0.022 & 1.14 & 1.10 \\
\hline & \multirow{3}{*}{$\mathrm{P}$} & {$[5]$} & $>300$ & $5.0-50$ & 524 & 19.6 & 0.037 & 1.14 & 1.07 \\
\hline & & {$[8]$} & - & 15.0 & 505 & - & - & 1.11 & - \\
\hline & & Producer & - & - & 520 & 18.2 & 0.035 & 1.19 & 1.13 \\
\hline & Average & & & & 570 & & & 1.20 & 1.12 \\
\hline \multirow{8}{*}{ Ferritic } & \multirow{4}{*}{$\mathrm{C}$} & Producer & - & - & 331 & 19.0 & 0.059 & 1.29 & 1.17 \\
\hline & & Producer & - & - & 349 & 21.4 & 0.062 & 1.45 & 1.31 \\
\hline & & Producer & - & $>1.0$ & 358 & 19.3 & 0.054 & 1.51 & 1.38 \\
\hline & & Producer & 438 & $1.25-2.0$ & 352 & 16.9 & 0.048 & 1.21 & 1.12 \\
\hline & \multirow[t]{2}{*}{$\mathrm{H}$} & Producer & - & - & 354 & 34.0 & 0.097 & 1.46 & 1.25 \\
\hline & & Producer & - & - & 371 & 26.4 & 0.071 & 1.33 & 1.18 \\
\hline & $\mathrm{P}$ & Producer & - & - & 347 & 37.0 & 0.107 & 1.39 & 1.16 \\
\hline & Average & & & & 352 & & & 1.38 & 1.22 \\
\hline
\end{tabular}


Table 2: Statistical data on material ultimate tensile strength

\begin{tabular}{|c|c|c|c|c|c|c|c|c|}
\hline $\begin{array}{l}\text { Material } \\
\text { type }\end{array}$ & $\begin{array}{l}\text { Product } \\
\text { type }\end{array}$ & Source & $\begin{array}{l}\text { No. of } \\
\text { tests } \mathrm{n}\end{array}$ & $\begin{array}{l}\text { Thickness } \\
\text { range (mm) }\end{array}$ & $\begin{array}{l}\mathrm{f}_{\mathrm{u}, \text { mean }} \\
\left(\mathrm{N} / \mathrm{mm}^{2}\right)\end{array}$ & $\begin{array}{l}\sigma \\
\left(\mathrm{N} / \mathrm{mm}^{2}\right)\end{array}$ & $\mathrm{COV}$ & $\frac{f_{u, \text { mean }}}{f_{u, \text { min }}}$ \\
\hline \multirow{9}{*}{ Austenitic } & \multirow{2}{*}{$\mathrm{C}$} & {$[4]$} & 2572 & $2.49-6.35$ & 609 & 10.6 & 0.017 & 1.15 \\
\hline & & Producer & - & - & 639 & 23.0 & 0.034 & 1.18 \\
\hline & \multirow{2}{*}{$\mathrm{H}$} & {$[6,7]$} & - & 4.0 & 601 & - & - & 1.15 \\
\hline & & Producer & - & - & 613 & 14.3 & 0.023 & 1.17 \\
\hline & \multirow{4}{*}{$\mathrm{P}$} & {$[5]$} & $>3000$ & $5.0-50$ & 596 & 14.8 & 0.025 & 1.16 \\
\hline & & {$[6,7]$} & - & 15.0 & 580 & - & - & 1.13 \\
\hline & & Producer & 1368 & - & 600 & 17.4 & 0.029 & 1.15 \\
\hline & & Producer & - & - & 580 & 15.8 & 0.027 & 1.13 \\
\hline & Average & & & & 606 & & & 1.15 \\
\hline \multirow{12}{*}{ Duplex } & \multirow{5}{*}{$\mathrm{C}$} & {$[4]$} & 239 & $2.49-6.35$ & 812 & 12.1 & 0.015 & 1.23 \\
\hline & & {$[8]$} & - & 1.0 & 845 & - & - & 1.21 \\
\hline & & Producer & 5747 & $0.4-3.5$ & 829 & 23.6 & 0.029 & 1.21 \\
\hline & & Producer & - & - & 806 & 28.1 & 0.036 & 1.18 \\
\hline & & Producer & - & $<6.4$ & 752 & 21.0 & 0.028 & 1.07 \\
\hline & \multirow{3}{*}{$\mathrm{H}$} & {$[8]$} & - & 4.0 & 798 & - & - & 1.16 \\
\hline & & Producer & - & - & 775 & 28.7 & 0.038 & 1.16 \\
\hline & & Producer & - & ¡ 10 & 718 & 7.0 & 0.010 & 1.06 \\
\hline & \multirow{3}{*}{$\mathrm{H}$} & {$[5]$} & $>300$ & $5.0-50$ & 763 & 13.7 & 0.018 & 1.19 \\
\hline & & {$[8]$} & - & 15.0 & 725 & - & - & 1.12 \\
\hline & & Producer & - & - & 742 & 18.8 & 0.025 & 1.16 \\
\hline & Average & & & & 775 & & & 1.16 \\
\hline \multirow{8}{*}{ Ferritic } & \multirow{4}{*}{$\mathrm{C}$} & Producer & - & - & 493 & 17.6 & 0.036 & 1.16 \\
\hline & & Producer & - & - & 504 & 18.8 & 0.037 & 1.17 \\
\hline & & Producer & - & $>1.0$ & 512 & 17.3 & 0.034 & 1.20 \\
\hline & & Producer & 438 & $1.25-2.0$ & 500 & 12.1 & 0.024 & 1.16 \\
\hline & \multirow[t]{2}{*}{$\mathrm{H}$} & Producer & - & - & 488 & 23.7 & 0.048 & 1.14 \\
\hline & & Producer & - & - & 512 & 30.4 & 0.059 & 1.14 \\
\hline & $\mathrm{P}$ & Producer & - & - & 512 & 35.0 & 0.068 & 1.14 \\
\hline & Average & & & & 503 & & & 1.16 \\
\hline
\end{tabular}


Table 3: Dimensional variation (i.e. ratios of measured to nominal values) of key dimensions of SHS and RHS

\begin{tabular}{lccc}
\hline Dimension & Depth $(\mathrm{h})$ & Breadth $(\mathrm{b})$ & Thickness $(\mathrm{t})$ \\
\hline Mean & 0.9999 & 1.0027 & 0.9755 \\
Standard deviation & 0.0205 & 0.0304 & 0.0362 \\
Coefficient of variation & 0.0205 & 0.0304 & 0.0362 \\
\hline
\end{tabular}

Table 4: Dimensional variation (i.e. ratios of measured to nominal values) of key dimensions of CHS

\begin{tabular}{lcc}
\hline Dimension & Outer diameter $(\mathrm{D})$ & Thickness $(\mathrm{t})$ \\
\hline Mean & 0.9853 & 0.9965 \\
Standard deviation & 0.0285 & 0.0138 \\
Coefficient of variation & 0.0289 & 0.0138 \\
\hline
\end{tabular}

Table 5: Dimensional variation (i.e. ratios of measured to nominal values) of key dimensions of I-sections

\begin{tabular}{lcccc}
\hline Dimension & Depth $(\mathrm{h})$ & Breadth $(\mathrm{b})$ & Web thickness $\left(\mathrm{t}_{\mathrm{w}}\right)$ & Flange thickness $\left(\mathrm{t}_{\mathrm{f}}\right)$ \\
\hline Mean & 1.0141 & 0.9977 & 0.9991 & 0.9994 \\
Standard deviation & 0.0369 & 0.0132 & 0.0151 & 0.0182 \\
Coefficient of variation & 0.0364 & 0.0132 & 0.0151 & 0.0182 \\
\hline
\end{tabular}

Table 6: Calculated values for the COV of geometric properties $\mathrm{V}_{\text {geometry }}$ for stainless steel sections

\begin{tabular}{lcc}
\hline Cross-section shape & Compression & Bending \\
\hline SHS/RHS & 0.0412 & 0.0486 \\
CHS & 0.0325 & 0.0606 \\
I-section & 0.0214 & 0.0495 \\
\hline
\end{tabular}


Table 7: Summary of statistical analysis results for cross-section compression resistance

\begin{tabular}{lccccccccc}
\hline Section type & Material & No. of tests n & $\mathrm{b}$ & Over-strength & $\mathrm{k}_{\mathrm{d}, \mathrm{n}}$ & $\mathrm{V}_{\delta}$ & $\mathrm{V}_{\mathrm{f}_{\mathrm{y}}}$ & $\mathrm{V}_{\text {Geometry }}$ & $\gamma_{\mathrm{M} 0}$ \\
\hline SHS/RHS & Austenitic & 71 & 1.245 & 1.30 & 3.14 & 0.156 & 0.060 & 0.05 & 1.08 \\
I-section & Austenitic & 20 & 1.067 & 1.30 & 3.30 & 0.099 & 0.060 & 0.05 & 1.09 \\
Angle & Austenitic & 12 & 1.122 & 1.30 & 3.40 & 0.110 & 0.060 & 0.05 & 1.07 \\
Channel & Austenitic & 11 & 1.099 & 1.30 & 3.40 & 0.125 & 0.060 & 0.05 & 1.15 \\
Lipped channel & Austenitic & 12 & 0.974 & 1.30 & 3.40 & 0.088 & 0.060 & 0.05 & 1.16 \\
CHS & Austenitic & 19 & 0.968 & 1.30 & 3.23 & 0.135 & 0.060 & 0.05 & 1.32 \\
\hline SHS/RHS & Duplex & 24 & 1.143 & 1.10 & 3.14 & 0.083 & 0.030 & 0.05 & 1.10 \\
I-section & Duplex & 5 & 1.202 & 1.10 & 3.30 & 0.032 & 0.030 & 0.05 & 1.06 \\
CHS & Duplex & 7 & 1.295 & 1.10 & 3.23 & 0.032 & 0.030 & 0.05 & 0.86 \\
\hline SHS/RHS & Ferritic & 9 & 1.073 & 1.20 & 3.14 & 0.054 & 0.045 & 0.05 & 1.02 \\
I-section & Ferritic & 7 & 1.099 & 1.20 & 3.30 & 0.044 & 0.045 & 0.05 & 0.98 \\
CHS & Ferritic & 4 & 1.182 & 1.20 & 3.23 & 0.036 & 0.045 & 0.05 & 0.90 \\
\hline
\end{tabular}

Table 8: Summary of statistical analysis results for cross-section bending resistance

\begin{tabular}{llcccccccc}
\hline Section type & Material & No. of tests $\mathrm{n}$ & $\mathrm{b}$ & Over-strength & $\mathrm{k}_{\mathrm{d}, \mathrm{n}}$ & $\mathrm{V}_{\delta}$ & $\mathrm{V}_{\mathrm{f}_{\mathrm{y}}}$ & $\mathrm{V}_{\text {Geometry }}$ & $\gamma_{\mathrm{M} 0}$ \\
\hline RHS/SHS & Austenitic & 45 & 1.296 & 1.30 & 3.25 & 0.120 & 0.060 & 0.05 & 0.95 \\
I-section & Austenitic & 5 & 1.136 & 1.30 & 4.08 & 0.056 & 0.060 & 0.05 & 0.94 \\
CHS & Austenitic & 8 & 1.272 & 1.30 & 4.33 & 0.122 & 0.060 & 0.05 & 1.08 \\
\hline RHS/SHS & Duplex & 12 & 1.219 & 1.10 & 3.25 & 0.095 & 0.030 & 0.05 & 1.07 \\
I-section & Duplex & 8 & 1.342 & 1.10 & 4.08 & 0.089 & 0.030 & 0.05 & 1.02 \\
CHS & Duplex & 3 & 1.319 & 1.10 & 4.33 & 0.011 & 0.030 & 0.05 & 0.83 \\
\hline RHS/SHS & Ferritic & 8 & 1.116 & 1.20 & 3.25 & 0.057 & 0.03 & 0.05 & 0.99 \\
\hline
\end{tabular}

Table 9: Summary of statistical analysis results for flexural buckling resistance

\begin{tabular}{llcccccccc}
\hline Section type & Material & No. of tests $\mathrm{n}$ & $\mathrm{b}$ & Over-strength & $\mathrm{k}_{\mathrm{d}, \mathrm{n}}$ & $\mathrm{V}_{\delta}$ & $\mathrm{V}_{\mathrm{f}_{\mathrm{y}}}$ & $\mathrm{V}_{\text {Geometry }}$ & $\gamma_{\mathrm{M} 1}$ \\
\hline RHS/SHS & Austenitic & 67 & 1.070 & 1.30 & 3.14 & 0.094 & 0.060 & 0.05 & 1.16 \\
I-section & Austenitic & 14 & 1.008 & 1.30 & 3.30 & 0.070 & 0.060 & 0.05 & 1.13 \\
CHS & Austenitic & 12 & 0.985 & 1.30 & 3.23 & 0.168 & 0.060 & 0.05 & 1.57 \\
\hline RHS/SHS & Duplex & 25 & 1.062 & 1.10 & 3.14 & 0.075 & 0.030 & 0.05 & 1.22 \\
I-section & Duplex & 3 & 1.026 & 1.10 & 3.30 & 0.009 & 0.030 & 0.05 & 1.13 \\
\hline RHS/SHS & Ferritic & 14 & 0.984 & 1.20 & 3.14 & 0.070 & 0.045 & 0.05 & 1.24 \\
\hline
\end{tabular}


Table 10: Summary of statistical analysis results for torsional-flexural buckling resistance

\begin{tabular}{llcccccccc}
\hline Section type & Material & No. of tests $\mathrm{n}$ & $\mathrm{b}$ & Over-strength & $\mathrm{k}_{\mathrm{d}, \mathrm{n}}$ & $\mathrm{V}_{\delta}$ & $\mathrm{V}_{\mathrm{f}_{\mathrm{y}}}$ & $\mathrm{V}_{\mathrm{Geometry}}$ & $\gamma_{\mathrm{M} 1}$ \\
\hline Hat-section & Austenitic & 19 & 1.023 & 1.30 & 3.24 & 0.099 & 0.060 & 0.05 & 1.16 \\
Hat-section & Ferritic & 44 & 1.037 & 1.20 & 3.24 & 0.101 & 0.045 & 0.05 & 1.22 \\
\hline
\end{tabular}

Table 11: Summary of statistical analysis results for lateral-torsional buckling resistance

\begin{tabular}{llcccccccc}
\hline Section type & Material & No. of tests $\mathrm{n}$ & $\mathrm{b}$ & Over-strength & $\mathrm{k}_{\mathrm{d}, \mathrm{n}}$ & $\mathrm{V}_{\delta}$ & $\mathrm{V}_{\mathrm{f}_{\mathrm{y}}}$ & $\mathrm{V}_{\mathrm{Geometry}}$ & $\gamma_{\mathrm{M} 1}$ \\
\hline I-section & Austenitic & 14 & 1.066 & 1.30 & 3.36 & 0.112 & 0.060 & 0.05 & 1.19 \\
I-section & Ferritic & 16 & 1.368 & 1.20 & 3.36 & 0.152 & 0.045 & 0.05 & 1.13 \\
\hline
\end{tabular}

Table 12: Summary of statistical analysis results for shear buckling resistance

\begin{tabular}{llcccccccc}
\hline Section type & Material & No. of tests $\mathrm{n}$ & $\mathrm{b}$ & Over-strength & $\mathrm{k}_{\mathrm{d}, \mathrm{n}}$ & $\mathrm{V}_{\delta}$ & $\mathrm{V}_{\mathrm{f}_{\mathrm{y}}}$ & $\mathrm{V}_{\text {Geometry }}$ & $\gamma_{\mathrm{M} 1}$ \\
\hline I-section & Austenitic & 19 & 1.132 & 1.30 & 3.48 & 0.059 & 0.060 & 0.05 & 1.08 \\
I-section & Duplex & 7 & 1.289 & 1.10 & 3.48 & 0.113 & 0.030 & 0.05 & 1.19 \\
\hline
\end{tabular}

Table 13: Summary of statistical analysis results for bolted shear connections

\begin{tabular}{llcccccccc}
\hline Section type & Material & No. of tests $\mathrm{n}$ & $\mathrm{b}$ & Over-strength & $\mathrm{k}_{\mathrm{d}, \mathrm{n}}$ & $\mathrm{V}_{\delta}$ & $\mathrm{V}_{\mathrm{f}_{\mathrm{u}}}$ & $\mathrm{V}_{\mathrm{Geometry}}$ & $\gamma_{\mathrm{M} 2}$ \\
\hline Shear & Austenitic & 11 & 1.042 & 1.10 & 3.32 & 0.048 & 0.035 & 0.05 & 1.12 \\
Bearing & Austenitic & 2 & 1.475 & 1.10 & 3.32 & 0.015 & 0.035 & 0.05 & 0.75 \\
Net section & Austenitic & 8 & 1.189 & 1.10 & 3.32 & 0.020 & 0.035 & 0.05 & 0.93 \\
\hline Shear & Duplex & 7 & 1.020 & 1.10 & 3.32 & 0.042 & 0.035 & 0.05 & 1.13 \\
Net section & Duplex & 2 & 1.196 & 1.10 & 3.32 & 0.083 & 0.035 & 0.05 & 1.07 \\
\hline Bearing & Ferritic & 3 & 1.346 & 1.10 & 3.32 & 0.021 & 0.035 & 0.05 & 0.85 \\
Net section & Ferritc & 9 & 1.168 & 1.10 & 3.32 & 0.075 & 0.035 & 0.05 & 1.09 \\
\hline
\end{tabular}

Table 14: Summary of statistical analysis results for welded connections

\begin{tabular}{llcccccccc}
\hline Section type & Material & No. of tests $\mathrm{n}$ & $\mathrm{b}$ & Over-strength & $\mathrm{k}_{\mathrm{d}, \mathrm{n}}$ & $\mathrm{V}_{\delta}$ & $\mathrm{V}_{\mathrm{f}_{\mathrm{u}}}$ & $\mathrm{V}_{\mathrm{Geometry}}$ & $\gamma_{\mathrm{M} 2}$ \\
\hline Fillet weld & Austenitic & 23 & 1.033 & 1.10 & 3.32 & 0.106 & 0.035 & 0.05 & 1.32 \\
Fillet weld & Duplex & 23 & 1.140 & 1.10 & 3.32 & 0.115 & 0.035 & 0.05 & 1.23 \\
\hline
\end{tabular}




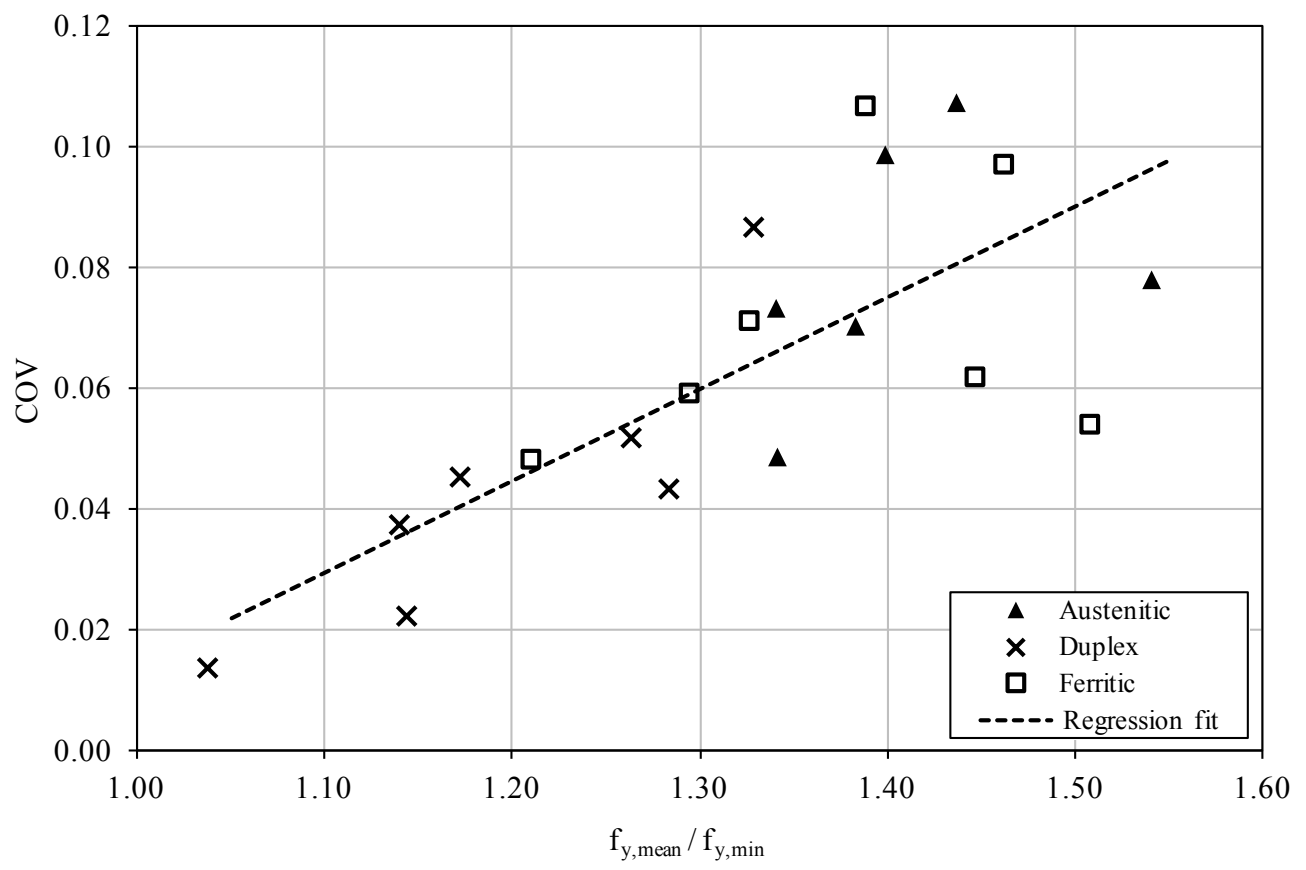

Figure 1: Relationship between $\mathrm{f}_{\mathrm{y}, \text { mean }} / \mathrm{f}_{\mathrm{y}, \text { min }}$ and COV

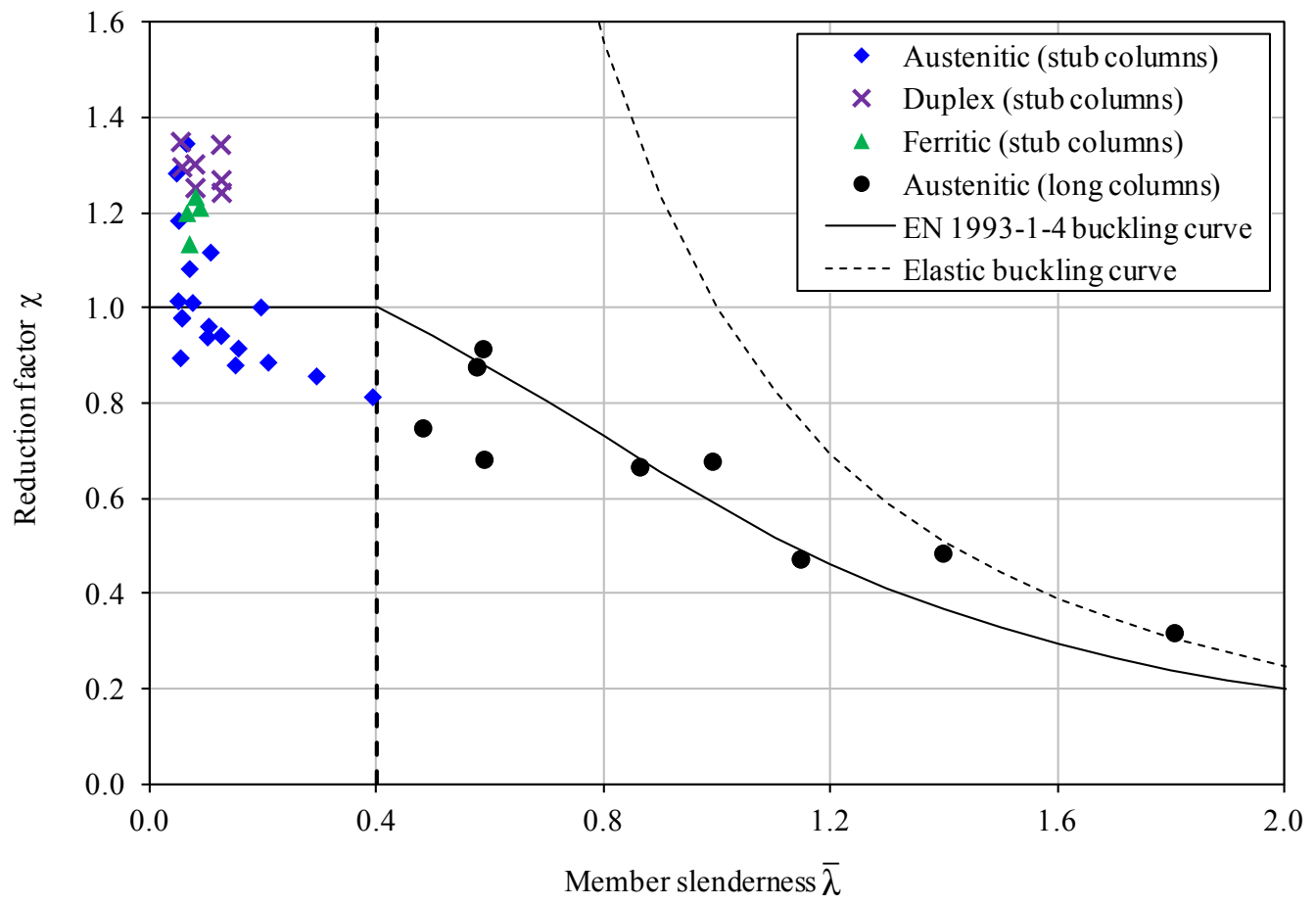

Figure 2: Comparison of CHS compression test data with EN 1993-1-4 buckling curve 


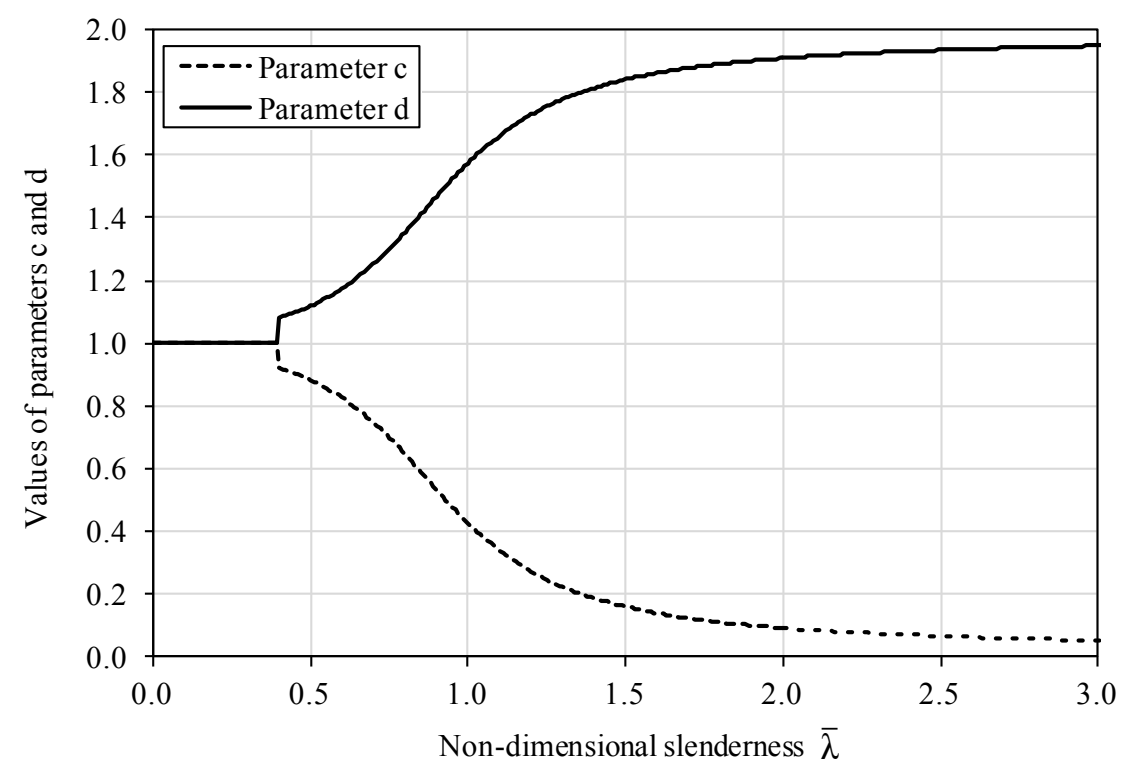

Figure 3: The powers a or b versus non-dimensional slenderness $\bar{\lambda}$.

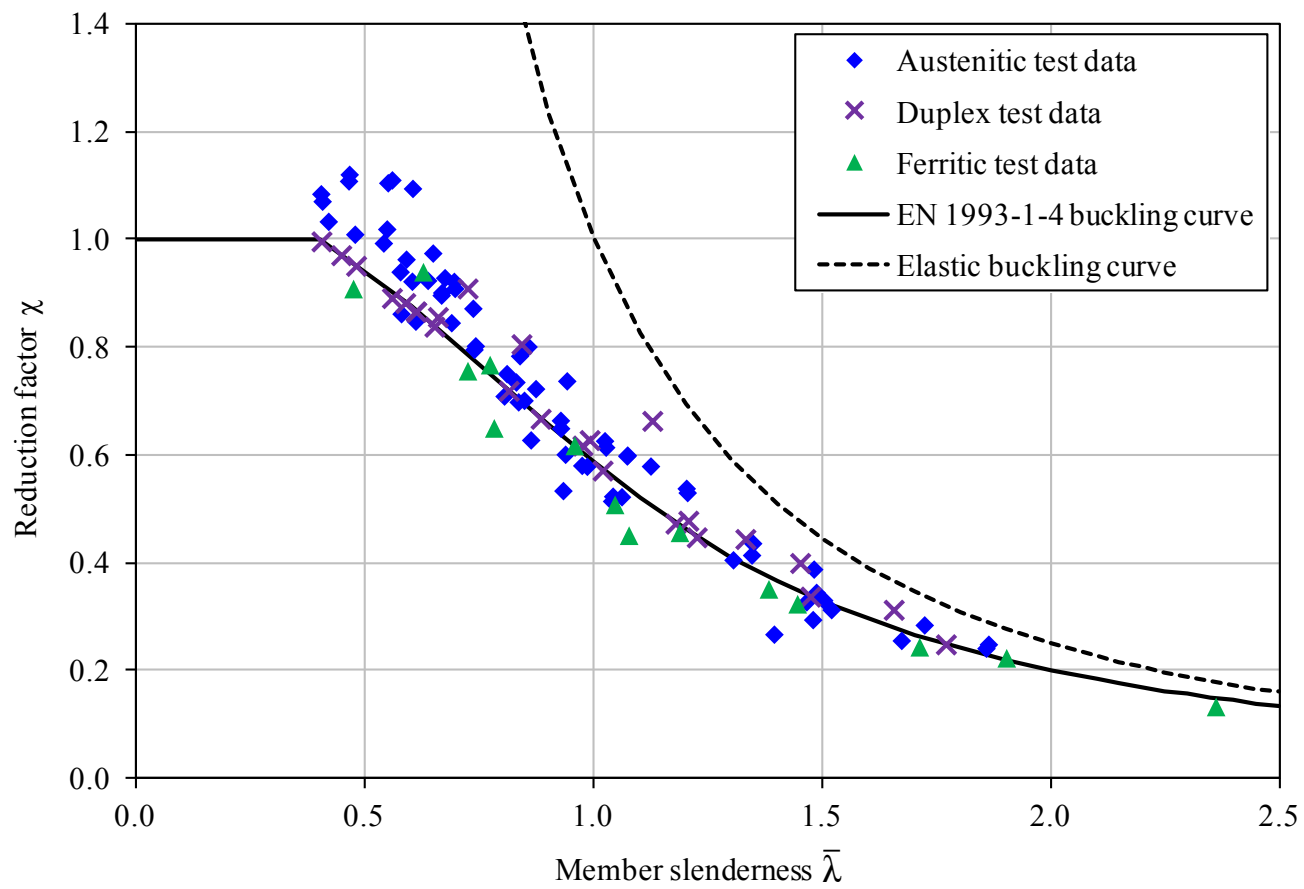

Figure 4: SHS/RHS column buckling test data and EN 1993-1-4 buckling curve 


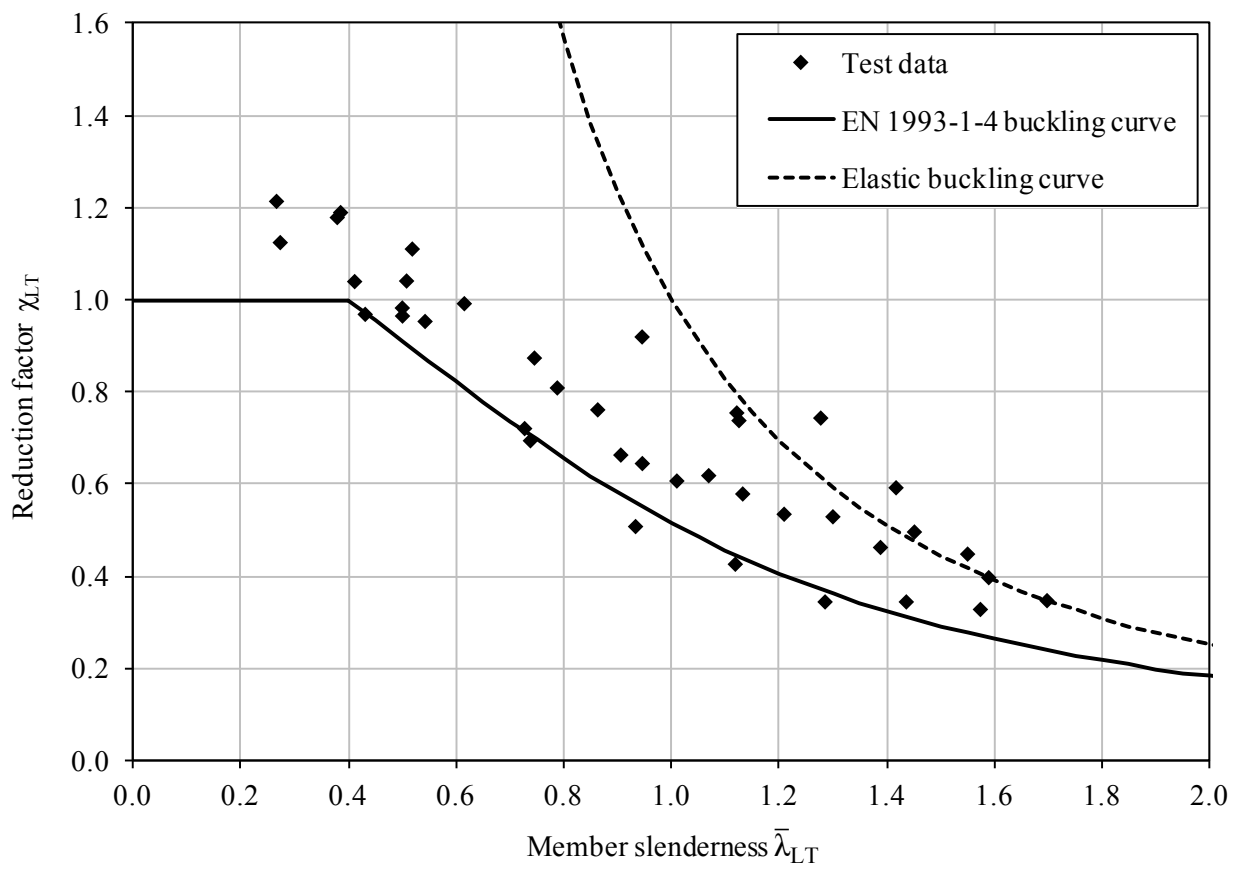

Figure 5: Lateral-torsional buckling test data with EN 1993-1-1 buckling curve 